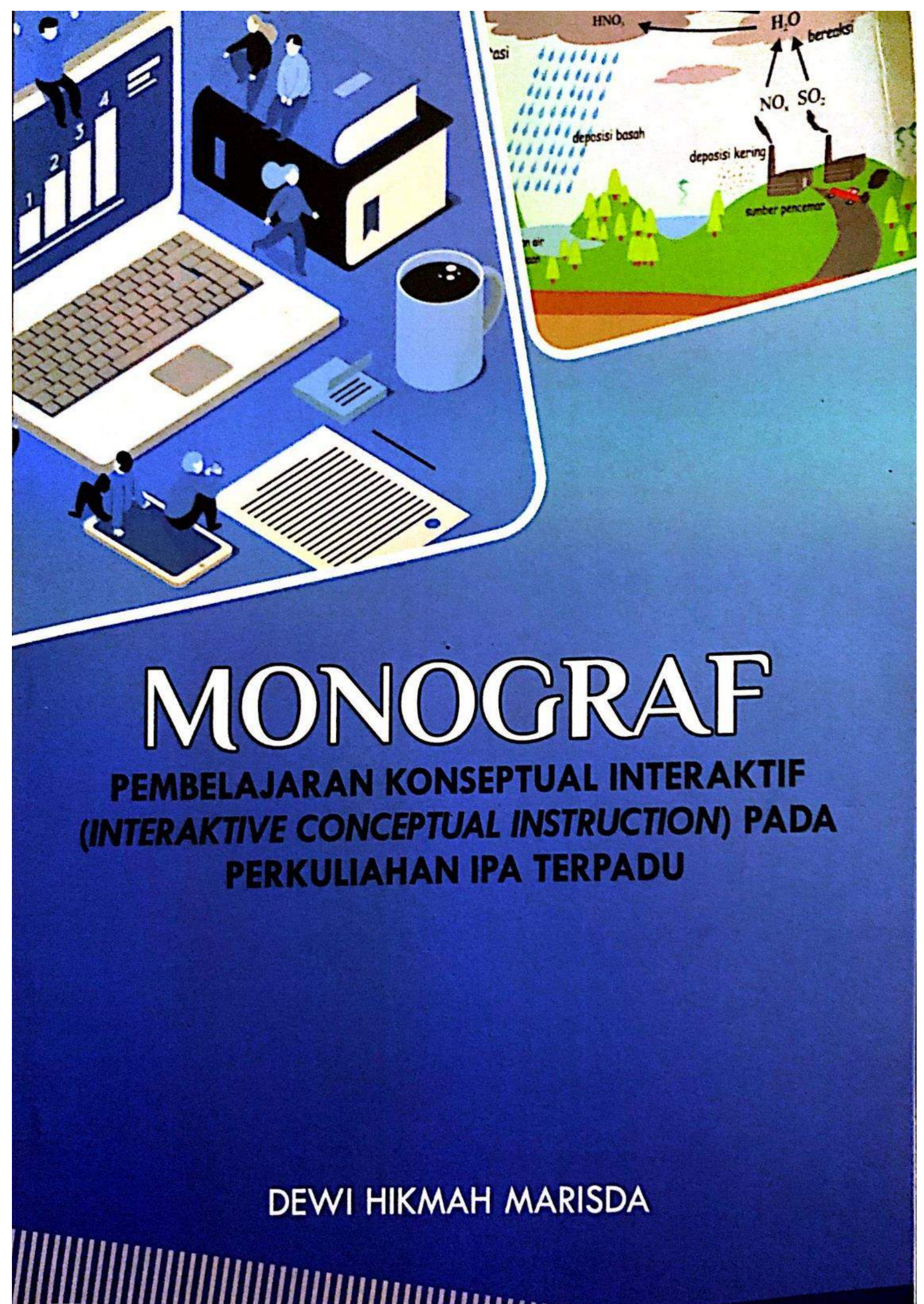


Dewi Hikmah Marisda

\section{MONOGRAF \\ PEMBELAJARAN KONSEPTUAL INTERAKTIF \\ (INTERACTIVE CONCEPTUAL INSTRUCTION) PADA PERKULIAHAN IPA TERPADU}

LPP UNISMUH MAKASSAR

2020 


\section{MONOGRAF}

PEMBELAJARAN KONSEPTUAL INTERAKTIF

(INTERACTIVE CONCEPTUAL INSTRUCTION) PADA

PERKULIAHAN IPA TERPADU

Penulis:

Dewi Hikmah Marisda

ISBN : 978-623-7349-14-3

Editor:

Riskawati

Layout:

Mutmainnah

Desain sampul dan tata letak

Top Media Art

Penerbit:

LPP UNISMUH MAKASSAR

ANGGOTA IKAPI

No. 021/ Anggota Luar Biasa/SSL/2019

Cetakan Pertama, 2020

Hak cipta dilindungi Undang-Undang

Dilarang memperbanyak karya tulis ini dalam bentuk

Dan dengan cara apapun tanpa izin dari penerbit.

Perpustakaan Nasional: Katalog Dalam Terbitan (KDT) 


\section{KATA PENGANTAR}

Bismillahirrahmanirrahim. Dengan menyebut nama Allah yang Maha Pemurah lagi Maha Penyayang. Puji syukur kehadirat Allah SWT yang telah melimpahkan rahmat-Nya berupa kesempatan dan pengetahuan sehingga penulis dapat menyelesaikan buku monograf yang berjudul "Pembelajaran

\section{Konseptual Interaktif (Interactive Conceptual Instruction) pada Perkuliahan IPA Terpadu".}

Shalawat dan salam semoga selalu dilimpahkan kepada Nabi Muhammad SAW, yang telah membawa risalah Islam yang penuh dengan ilmu pengetahuan, sehingga dapat menjadi bekal hidup kita di dunia dan di akhirat kelak. Teriring doa semoga syafaat Nabi besar Muhammad SAW selalu dilimpahkan kepada kepada saya, keluarga saya, juga kita semua di dunia dan di akhirat. Amin.

Dengan segala kerendahan hati, saya ucapkan terima kasih kepada :

1. Lembaga Penelitian, Pengembangan dan Pengabdian Masyarakat (LP3M) Universitas Muhammadiyah Makassar yang telah mendanai penelitian ini melalui hibah internal perguruan tinggi.

2. Seluruh dosen prodi Pendidikan Fisika UNISMUH Makassar yang telah memberikan masukan dan kritikan membangun kepada saya.

3. Kedua orang tua saya, Bapak Muhammad Sain dan Ibu Nurwanati yang selalu membimbing penulis dalam segala hal. Juga adik saya (Dewi Purnama Windasari, SKM., M.Kes) atas motivasinya.

4. Suami (Ilham Hadianto) dan anakku tersayang (Muhammad Albyaksa) yang telah memberi kesempatan kepada saya untuk terus berkarya.

5. Seluruh pihak tak terkecuali yang telah mendukung penyusunan buku monograf ini. 
Buku monograf ini bertujuan memberikan gambaran tentang model pembelajaran yang tepat digunakan pada perkuliahan IPA Terpadu. Buku ini juga menjelaskan penggunaan media pembelajaran interaktif yang disandingkan dengan model pembelajaran konseptual interaktif pada perkuliahan IPA Terpadu. Selanjutnya, buku monograf ini diharapkan dapat menjadi referensi bagi pemerhati pendidikan dan masyarakat pada umumnya dalam hal menambah khasanah pengetahuan dalam bidang pendidikan, khususnya proses pembelajaran.

Penulis menyadari bahwa dalam penulisan buku monograf ini terdapat banyak kekurangan, oleh karena itu penulis mengharapkan saran dan kritik yang membangun demi perbaikan selanjutnya. Semoga buku monograf ini dapat memberikan manfaat bagi kita semua. Amin.

Makassar, 14 Januari 2020

Penulis 


\section{DAFTAR ISI}

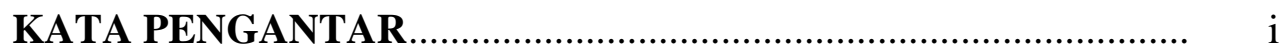

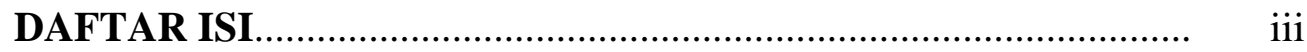

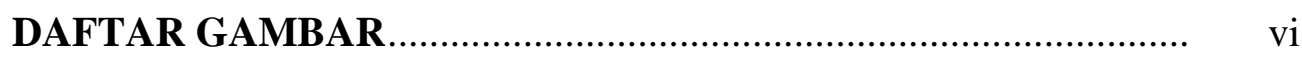

\section{BAB I PENDAHULUAN}

Latar Belakang ..................................................................... 1

\section{BAB II PEMECAHAN MASALAH}

A. Penelitian Terdahulu........................................................... 5

B. Hasil Penelitian..................................................................... 6

1. Hasil Pemetaan Materi yang Sesuai dengan Model

Pembelajaran Konseptual Interaktif (ICI) dan Multimedia Interaktif Macromedia Flash .......................................... 6

2. Hasil Analisis Konsep pada Materi IPA Terpadu yang Telah Diidentifikasi .............................................................. 8

3. Hasil Identifikasi Materi IPA Terpadu yang Memungkinkan Mahasiswa Mengalami Miskonsepsi ............................... 9

4. Hasil Analisis Konsep pada Materi Teridentifikasi yang dapat Menimbulkan Miskonsepsi ............................................. 9

5. Hasil Rancangan (Story Board) Media Pembelajaran Berbasis Multimedia Interaktif dengan Menggunakan Model Pembelajaran Konseptual Interaktif pada Pembelajaran IPA

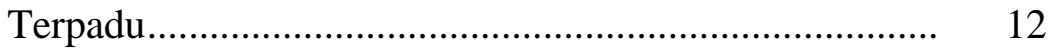

6. Hasil Uji Coba Software Terintegrasi ............................ 28

\section{BAB III DUKUNGAN TEORI}

A. Model Pembelajaran yang Berasal dari Teori Belajar

Konstruktivisme 
B. Model Pembelajaran Konseptual Interaktif........................... 32

C. Tahapan Model Pembelajaran Konseptual Interaktif ............. 33

D. Rasionalitas Penggunaan Pembelajaran Konseptual Interaktif dalam Proses Pembelajaran Sains ........................................ 35

E. Penggunaan Media dalam Pembelajaran Konseptual Interaktif 36 BAB IV KESIMPULAN

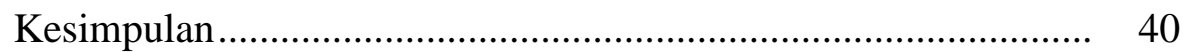

Daftar Pustaka ............................................................................... 41

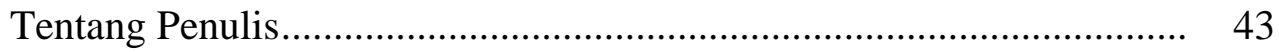




\section{DAFTAR GAMBAR}

Gambar 2.1. Peta konsep hujan asam

Gambar 2.2. Story board multimedia interaktif dengan macromedia flash pada perkuliahan IPA Terpadu screen 1

Gambar 2.3. Story board multimedia interaktif dengan macromedia flash pada perkuliahan IPA Terpadu screen 2 ........................... 14

Gambar 2.4. Story board multimedia interaktif dengan macromedia flash pada perkuliahan IPA Terpadu screen 2 .......................... 15

Gambar 2.5. Story board multimedia interaktif dengan macromedia flash pada perkuliahan IPA Terpadu screen 3

Gambar 2.6. Story board multimedia interaktif dengan macromedia flash pada perkuliahan IPA Terpadu screen 3

Gambar 2.7. Story board multimedia interaktif dengan macromedia flash pada perkuliahan IPA Terpadu screen 4

Gambar 2.8. Story board multimedia interaktif dengan macromedia flash pada perkuliahan IPA Terpadu screen 4

Gambar 2.9. Story board multimedia interaktif dengan macromedia flash pada perkuliahan IPA Terpadu screen 4

Gambar 2.10.Story board multimedia interaktif dengan macromedia flash pada perkuliahan IPA Terpadu screen 4

Gambar 2.11.Story board multimedia interaktif dengan macromedia flash pada perkuliahan IPA Terpadu screen 4

Gambar 2.12.Story board multimedia interaktif dengan macromedia flash pada perkuliahan IPA Terpadu screen 4 .

Gambar 2.13.Story board multimedia interaktif dengan macromedia flash pada perkuliahan IPA Terpadu screen 5

Gambar 2.14 Story board multimedia interaktif dengan macromedia flash pada perkuliahan IPA Terpadu screen 6 
Gambar 2.15.Story board multimedia interaktif dengan macromedia flash pada perkuliahan IPA Terpadu screen 6 .......................... 26

Gambar 2.16.Story board multimedia interaktif dengan macromedia flash pada perkuliahan IPA Terpadu screen 7

Gambar 2.17.Grafik persentase perolehan skor tes miskonsepsi pada konsep hujan asam 


\section{BAB I \\ PENDAHULUAN}

\section{Latar Belakang}

Perubahan proses pembelajaran IPA, khususnya pada tingkatan perguruan tinggi perlu diarahkan pada upaya melatih mahasiswa calon guru menggunakan potensi berpikir yang dimilikinya melalui interaksi sosial dalam pembelajaran. NRC (1996) mengungkapkan bahwa karakteristik pembelajaran Sains akan banyak menjalani aktivitas-aktivitas dan proses berpikir yang sama dengan para ilmuan yang sedang mengembangkan pengetahuan manusia tentang alam semesta. Namun, dalam prosesnya ditemukan sejumlah permasalahan bahwa para pendidik kurang begitu mengenal model pembelajaran yang mampu mengembangkan proses berpikir.

Mengingat pentingnya peranan IPA, di dalamnya mencakup fisika, biologi, dan kimia, sudah selayaknyalah penanganan proses pembelajaran IPA harus dilakukan dengan baik. Salah satu aspek penting yang perlu diperhatikan sehubungan dengan konten materi IPA fisika, biologi, dan kimia adalah bagaimana meramu materi dari masing-masing disiplin ilmu menjadi satu kesatuan yang utuh membentuk suatu kajian tersendiri yaitu IPA Terpadu kemudian menyampaikannya kepada mahasiswa secara benar dan menyenangkan dengan mempertimbangkan pemilihan pendekatan pembelajaran yang tepat sehingga mampu meningkatkan kualitas pembelajaran IPA Terpadu peserta didik baik dari segi proses berpikir tingkat tinggi hingga peningkatan kompetensi mahasiswa yang ditunjukkan dengan peningkatan prestasi belajar terutama pada wilayah miskonsepsi mahasiswa dan keterampilan berpikir kritis (KBKr) (Marisda, 2018).

Miskonsepsi terjadi pada semua tingkatan sekolah, tidak hanya pada siswa sekolah dasar tetapi juga pada perguruan tinggi. Demikian halnya dengan sejumlah mahasiswa yang telah (sedang) mengontrak mata kuliah IPA 
Terpadu juga mengalami miskonsepsi. Menurut Carin (1993) bahwa (maha)siswa akan tetap memiliki miskonsepsi meskipun telah diajar dengan model pembelajaran tradisional. Olehnya itu, Collete dan Chiappetta (1994) merekomendasikan guru sains memberikan pengajaran yang mengizinkan (maha)siswa untuk melihat atribut kritis dari konsep yang sedang mereka pelajari, secara bertahap bentuk pemahaman mereka dengan ide, melalui berbagai pengalaman, dan meminta (maha)siswa mencoba dengan apa yang mereka pikirkan dan percayai. Hal ini merupakan peran penting dari teori kontruktivis yang memberikan kesempatan kepada siswa untuk membangun pengetahuannya sendiri.

Pada proses pengkonstruksian, salah satu syarat yang harus dimiliki (maha)siswa adalah memiliki kemampuan membandingkan, mengambil keputusan mengenai persamaan atau perbedaan (Suparno, 1997). Kemampuan membandingkan, mengambil keputusan mengenai persamaan atau perbedaan merupakan ciri-ciri keterampilan berpikir berpikir kritis $(\mathrm{KBKr})$ (Schafesman, 2006). Oleh karena itu, Zero, D., (2011) menyatakan bahwa keterampilan berpikir kritis dapat digunakan untuk mengevaluasi informasi baru atau situasi-situasi atau membenarkan konsep yang awalnya miskonsepsi.

Mata kuliah IPA Terpadu merupakan salah satu mata kuliah yang sangat penting dibekalkan pada mahasiswa yang masih berada pada tingkat awal. Selain itu konten daripada mata kuliah IPA Terpadu ini memiliki keterkaitan langsung serta memberi kontribusi penting dalam pengembangan ilmu lainnya. Akan tetapi sampai saat ini IPA Terpadu masih kurang diminati, khususnya bagi siswa di tingkat SMP karena menganggap mata pelajaran ini sebagai mata pelajaran yang susah dan kompleks dikarenakan terlalu banyak materi dan rumus serta mengandung konsep-konsep yang abstrak sehingga tidak sedikit menimbulkan kesalahan dalam memahami konsep-konsep 
tersebut yang diistilahkan dengan miskonsepsi. Selain itu, persepsi bahwa materi IPA Terpadu terlalu berat dengan adanya tuntutan bagaimana memadukan konsep-konsep IPA Fisika, Biologi, dan Kimia serta aplikasi keterpaduannya dalam kehidupan sehari-hari peserta didik melahirkan suatu beban tersendiri di kalangan para siswa. Persepsi ini melahirkann pengetahuan dasar IPA Terpadu yang dimiliki oleh siswa SMP ketika melanjutkan studi pada tingkat perguruan tinggi menjadi sangat minim, sehingga berdampak pada kurangya kemampuan penguasaan konsep pada IPA Terpadu.

Lebih lanjut, permasalahan yang dialami oleh dosen pada saat melaksanakan proses pembelajaran IPA Terpadu yaitu adanya ketidakseragaman dasar pengetahuan yang dimiliki oleh mahasiswa, yakni sebagian mahasiswa ada yang masih sangat kurang pada materi-materi tertentu sedangkan sebagian lainnya sudah sangat menguasai materi tersebut. Sehingga, sebagai jalan tengahnya dosen harus selalu me-review materimateri yang dianggap urgen tetatpi kurang dikuasai oleh sebagian mahasiswa tersebut. Akan tetapi mahasiswa yang sudah menguasai materi tersebut merasakan bahwa kegiatan me-review materi merupakan kegiatan yang membosankan dan membuang waktu. Sebaliknya, bagi mereka yang masih belum memahami, pengulangan yang hanya bersifat review ini bermanfaat meskipun masih dirasakan sangat kurang.

Ada banyak model pembelajaran yang ditawarkan oleh para pakar pembelajar dengan harapan dapat mereduksi miskonsepsi dan meningkatkan keterampilan berpikir kritis mahasiswa terhadap konsep-konsep IPA Terpadu. Salah satu model pembelajaran yang dimaksud adalah Model Pembelajaran Konseptual Interaktif dengan menggunakan Multimedia Interaktif (MMI) Macromedia Flash. 
Pembahasan dalam buku monograf ini akan difokuskan pada permasalahan "Bagaimana penerapan pembelajaran konseptual interaktif dengan multimedia interaktif pada perkuliahan IPA Terpadu".

Buku monograf ini ditujukan kepada calon peneliti atau pemerhati pendidikan yang mengkaji tentang model pembelajaran yang tepat pada perkuliahan IPA Terpadu. 


\section{BAB II}

\section{PEMECAHAN MASALAH}

\section{A. Penelitian Terdahulu}

Model pembelajaran konseptual interaktif (interactive conceptual instruction, $I C I$ ) merupakan pembelajaran yang didesain dengan fokus pada penanaman konsep dikalangan mahasiswa memiliki keutamaan yaitu berfokus pada segi konseptual, mengutamakan interaksi kelas, menggunakan bahanbahan ajar berbasis penelitian, dan menggunakan teks (Savinainen \& Scott, 2004) sehingga sangat cocok jika dipadukan dengan penggunaan media berbasis teknologi komputer. Meskipun demikian, komponen penting yang memegang kunci keberhasilan dalam membangun budaya belajar berbasis teknologi dan informasi adalah kreatifitas dan kemampuan guru mengembangkan pengetahuan dan keterampilan, serta memfasilitasi pembelajaran. Selain itu, komponen lain yang ikut terlibat dalam keberhasilan pembelajaran yaitu kemampuan belajar mandiri mahasiswa, ketersediaan infrastruktur dan administrator yang kreatif.

Beberapa penelitian terdahulu yang terkait dengan penggunaan model pembelajaran konseptual interaktif (interactive conceptual instruction, ICI) menghasilkan bahwa pembelajaran dengan model ini efektif dalam membantu siswa dalam proses berpikir yang bermuara pada peningkatan kualitas proses dan hasil belajar. Hasil penelitian Suhandi et al., (2013) mengungkapkan bahwa pendekatan pembelajaran ICI dengan menggunakan media simulasi virtual dapat lebih meningkatkan pemahaman konsep dan meminimalkan miskonsepsi siswa terhadap konsep-konsep IPA Fisika. Serupa dengan hasil penelitian yang dilakukan oleh Cahyanti, et al., (2012) bahwa model pembelajaran ICI berorientasi pada kemampuan penalaran secara efektif dapat meningkatkan hasil belajar matematika siswa SD. Penelitian yang serupa juga 
dilakukan oleh Magfiro, et al., (2014) yang mencoba menerapkan model pembelajaran ICI untuk meningkatkan pemahaman konsep matematika siswa SMP. Hasil yang diperoleh bahwa model pembelajaran ini secara efektif mampu meningkatkan pemahaman siswa terhadap konsep matematika di SMP.

\section{B. Hasil Penelitian}

Hasil penelitian yang menggunakan Model Pembelajaran Konseptual Interaktif pada pembelajaran IPA Terpadu dapat diuraikan sebagai berikut :

1. Hasil Pemetaan Materi yang Sesuai dengan Model Pembelajaran Konseptual Interaktif (ICI) dan Multimedia Interaktif Macromedia Flash

Mata kuliah IPA Terpadu merupakan mata kuliah wajib dalam kelompok mata kuliah keahlian. Mata kuliah ini terbagi atas IPA Terpadu 1 dan IPA Terpadu 2. Konten mata kuliah keduanya meliputi materi keipaan yang terkait satu sama dalam konteks keterpaduan (Fisika, Kimia, dan Biologi). IPA Terpadu 1 diberikan pada semester 2 di tahun yang sama. Materi IPA Terpadu 2 merupakan kelanjutan dari IPA Terpadu 1.

Adapun struktur materi dalam mata kuliah IPA Terpadu 1 sebagai berikut.

\subsection{Pengertian Integrated Science}

Model-model keterpaduan dalam IPA (Fragmanted, connected, nested, sequenced, shared, webbed, threaded, integrated, immersed, and networked).

1.2 Materi dan perubahannya, meliputi: materi dan sifatnya, penggolongan materi, dan ikatan kimia. 
1.3 Klasifikasi Makhluk Hidup, meliputi; karakteristik makhluk hidup, tumbuhan dan klasifikasinya, hewan dan klasifikasinya.

1.4 Makhluk hidup dan lingkungannya, meliputi; konsep lingkungan hidup, ekosistem, jenis makanan dan daur hidup hewan, perubahan lingkungan, pencemaran, dan pemanasan global.

1.5 Energi dalam sistem kehidupan, meliputi; konsep energi dan sumber energi, transformasi energi dalam sel dan metabolism sel, respirasi, pencernaan makanan, dan fotosintesis.

1.6 Suhu dan perubahannya

1.7 Kalor dan perpindahannya

1.8 Listrik dan peralatan listrik

1.9 Kemagnetan dan pemanfaatannya dalam produk teknologi

Adapun struktur materi dalam mata kuliah IPA Terpadu 2 sebagai berikut.

1.1 Gerak pada makhluk hidup dan benda: gerak benda mati meliputi Gerak Lurus Beraturan (GLB) dan Gerak Lurus Berubah Beraturan (GLBB), gerak pada makhluk hidup meliputi gerak pada hewan dan tumbuhan.

1.2 Rangka, otot, dan pesawat sederhana: tulang penyusun rangka pada manusia, otot pada manusia, dan prinsip kerja pesawat sederhana, serta hubungan antara konsep pesawat sederhana, rangka dan otot manusia.

1.3 Struktur dan fungsi jaringan tumbuhan serta pemanfaatannya dalam teknologi; struktur dan fungsi jaringan pada akar, batang, dan daun dan aplikasi pemanfaatan teknologi terhadap struktur jaringan tumbuhan.

1.4 Sistem pencernaan makana: jenis dan fungsi bahan makanan, organ penyusun sistem pencernaan makanan pada manusia. 
1.5 Sistem transportasi: struktur dan fungsi sistem transportasi pada manusia dan tumbuhan, penerapan hukum Pascal terhadap konsep sistem transportasi pada manusia dan tumbuhan.

1.6 Sistem ekskresi: struktur dan fungsi sistem ekskresi pada manusia, dan cara pola hidup sehat dalam menjaga sistem eksresi.

1.7 Sistem indera pendengaran dan sistem sonar pada makhluk hidup: struktur dan fungsi organ sistem pendengaran pada manusia, konsep pendengaran dan hubungannya dengan konsep gelombang bunyi yang meliputi konsep frekuensi, periode, cepat rambat gelombang, Panjang gelombang, sistem sonar dan prinsip kerjanya serta pemanfaatan konsep sistem sonar pada teknologi.

1.8 Indera penglihatan dan alat optik: struktur dan fungsi penyusun organ indera penglihatan, proses pembentukan bayangan, prinsip kerja alat optik, dan pemanfaatan alat optik dalam kehidupan seharihari.

1.9 Sistem tata surya dan kehidupan di bumi : benda-benda langit penyusun sistem tata surya, konsep radiasi, peristiwa gerhana matahari dan bulan, dan struktur muka bumi dan jenis bencana yang ditimbulkan serta cara penanganannya.

1.10 Sifat bahan dan pemanfaatannya dalam kehidupan sehari-hari: sifat bahan dan pengelompokannya berdasarkan karakteristik dan penyusunnya, serta suhu dan tekanan.

2. Hasil Analisis Konsep pada Materi IPA Terpadu yang Telah Diidentifikasi

Berdasarkan hasil analisis materi dan beberapa pertimbangan para pengampu mata kuliah IPA Terpadu bahwa materi yang diangkat dalam mata kuliah ini diprioritaskan pada materi mata kuliah IPA 
Terpadu 1 dengan alasan bahwa materi dalam materi dalam mata kuliah IPA Terpadu 1 merupakan materi paling dasar yang wajib dikuasai oleh para mahasiswa sebelum melanjutkan mata kuliah IPA Terpadu 2. Salah satu topik yang diangkat dalam penelitian ini adalah Pencemaran lingkungan. Pertimbangan pemilihan materi ini adalah karakteristik materi ini sangat bersentuhan dengan permasalahan yang paling sering dan masih menjadi permasalahan di tengah masyarakat dalam kehisupan real (real situation).

3. Hasil Identifikasi Materi IPA Terpadu yang Memungkinkan Mahasiswa Mengalami Miskonsepsi

Materi pencemaran lingkungan merupakan salah satu materi dalam matakuliah IPA Terpadu 1 yang berpotensi menimbulkan miskonsepsi. Hal ini berdasarkan kajian karakteristik materi yang dominan bersifat abstrak jika tidak disertai dengan simulasi sehingga berpotensi menimbulkan kesalahan konsep atau dengan istilah lainnya miskonsepsi.

Adapun sub konsep yang difokuskan dalam penelitian ini adalah dampak pencemaran Hujan Asam. Adapun deskripsi indikator materi dari dampak pencemaran hujan asam yaitu: Mendiskripsikan akibat pencemaran udara; Menjelaskan konsep siklus air; Menjelaskan konsep hujan asam; dan Menjelaskan dampak hujan asam terhadap lingkungan.

4. Hasil Analisis Konsep pada Materi Teridentifikasi yang dapat Menimbulkan Miskonsepsi

Analisis konsep materi hujan asam disajikan dalam bentuk peta konsep dengan tujuan memudahkan dalam mengenal konsep-konsep terkait materi hujan asam yang materinya bersifat agak kompleks. 
Sajian materi hujan asam dalam bentuk peta konsep ditunjukkan pada bagan peta konsep berikut. 


\section{Gambar 2.1. Peta Konsep Hujan Asam}

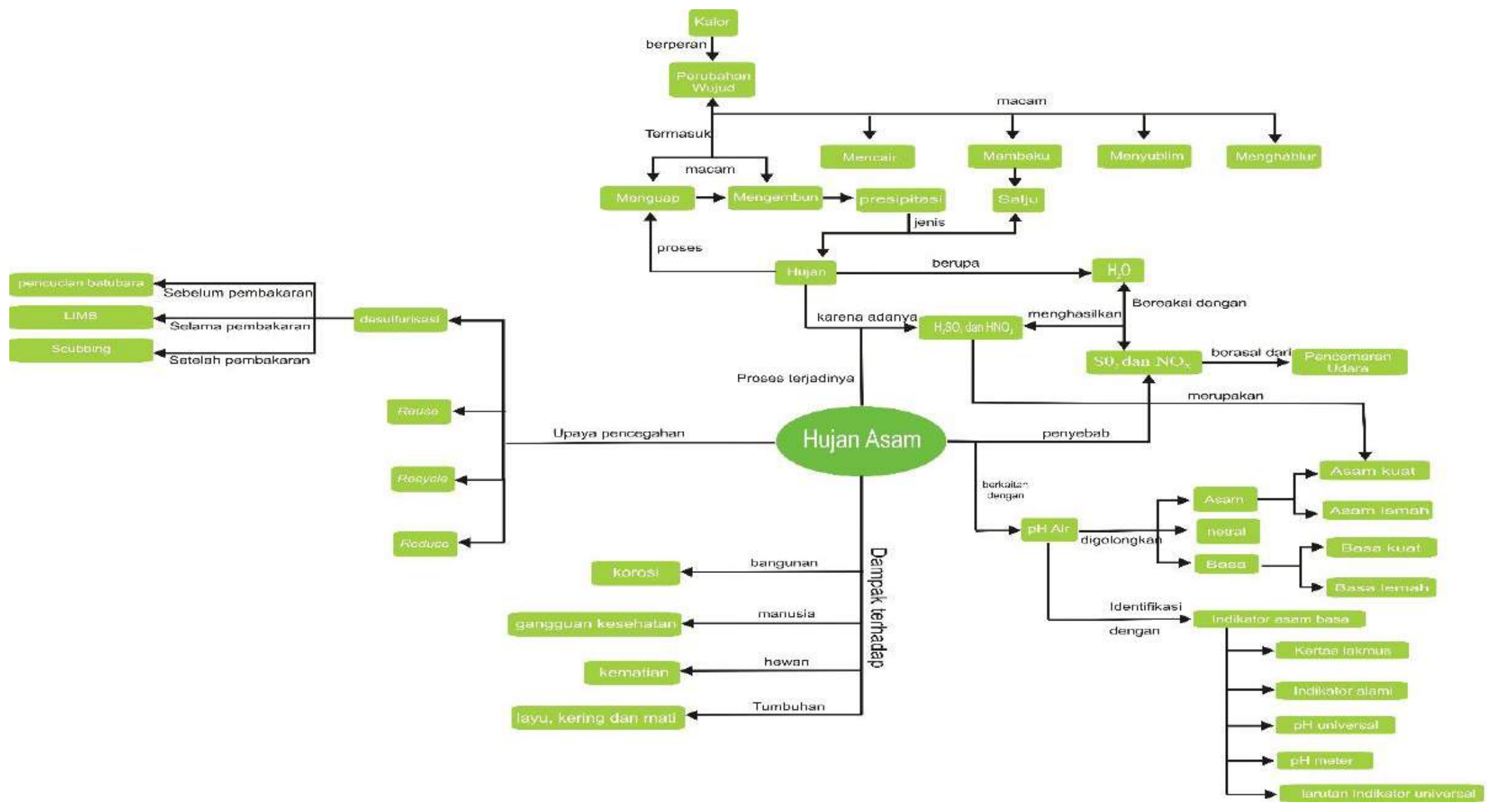


5. Hasil Rancangan (Story Board) Media Pembelajaran Berbasis Multimedia Interaktif dengan Menggunakan Model Pembelajaran Konseptual Interaktif pada Pembelajaran IPA Terpadu

Berdasarkan penentuan materi yang dilakukan melalui analisis materi ajar tersebut dirancang dalam bentuk story board sebagai acuan atau kerangka pembuatan media pembelajaran dalam bentuk Macromedia Flash. Berikut ini disajikan hasil perancangan story board materi ajar perkuliahan IPA Terpadu yang telah diseleksi berdasarkan hasil analisis pertimbangan. 


\section{Story Board}

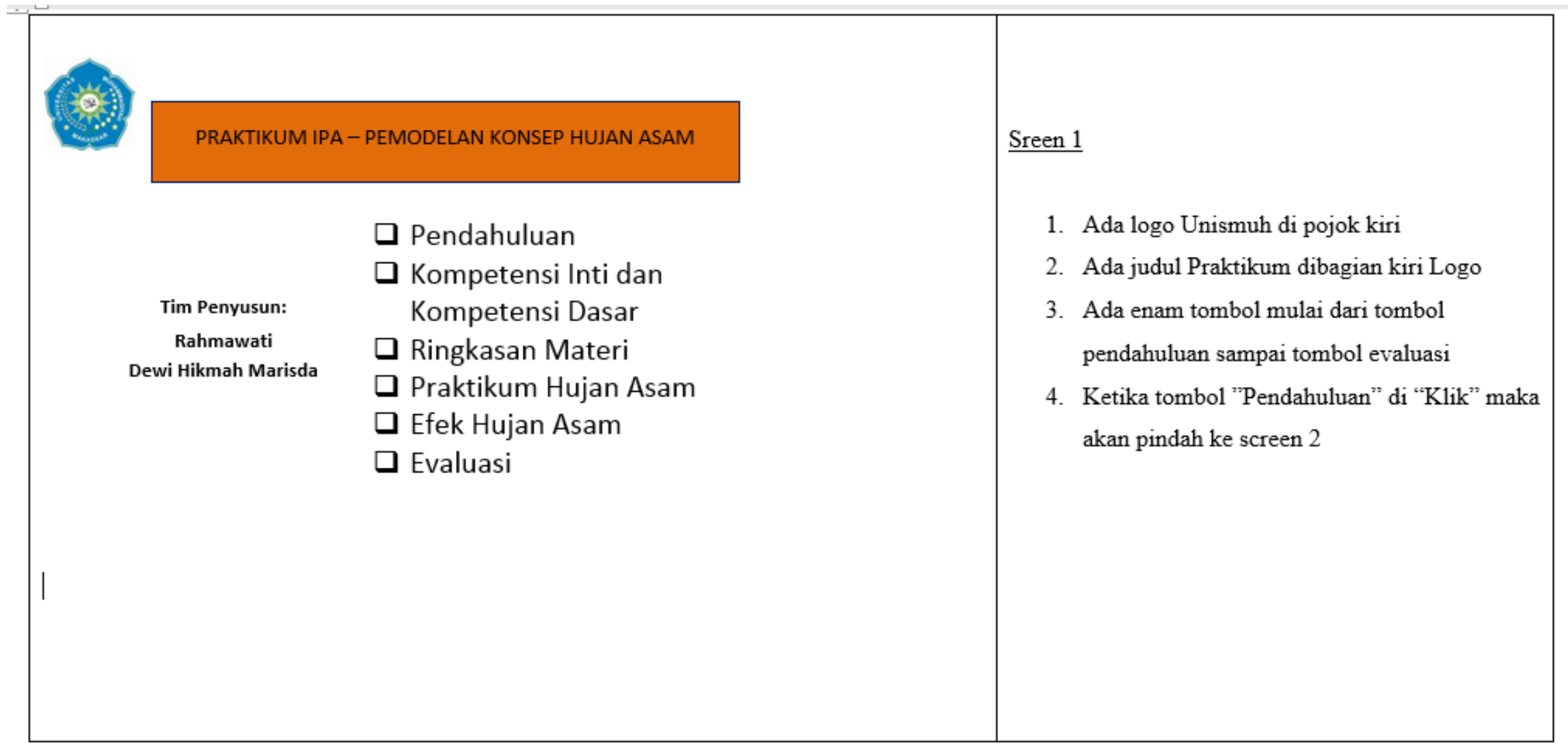

Gambar 2.2. Story Board Multimedia Interaktif dengan Makromedia Flash pada Perkuliahan IPA Terpadu Screen 1 


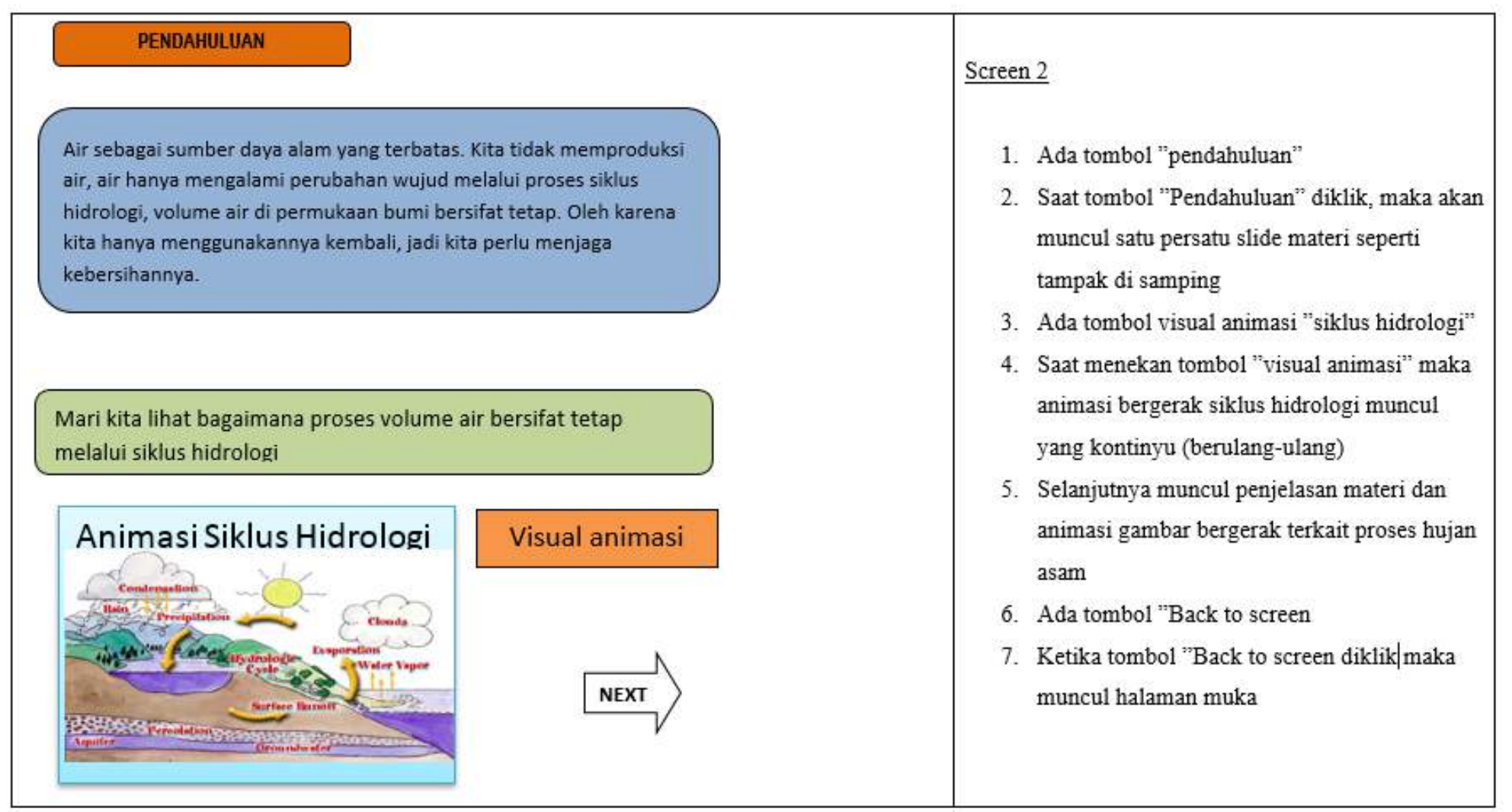

Gambar 2.3. Story Board Multimedia Interaktif dengan Makromedia Flash pada Perkuliahan IPA Terpadu Screen 2 


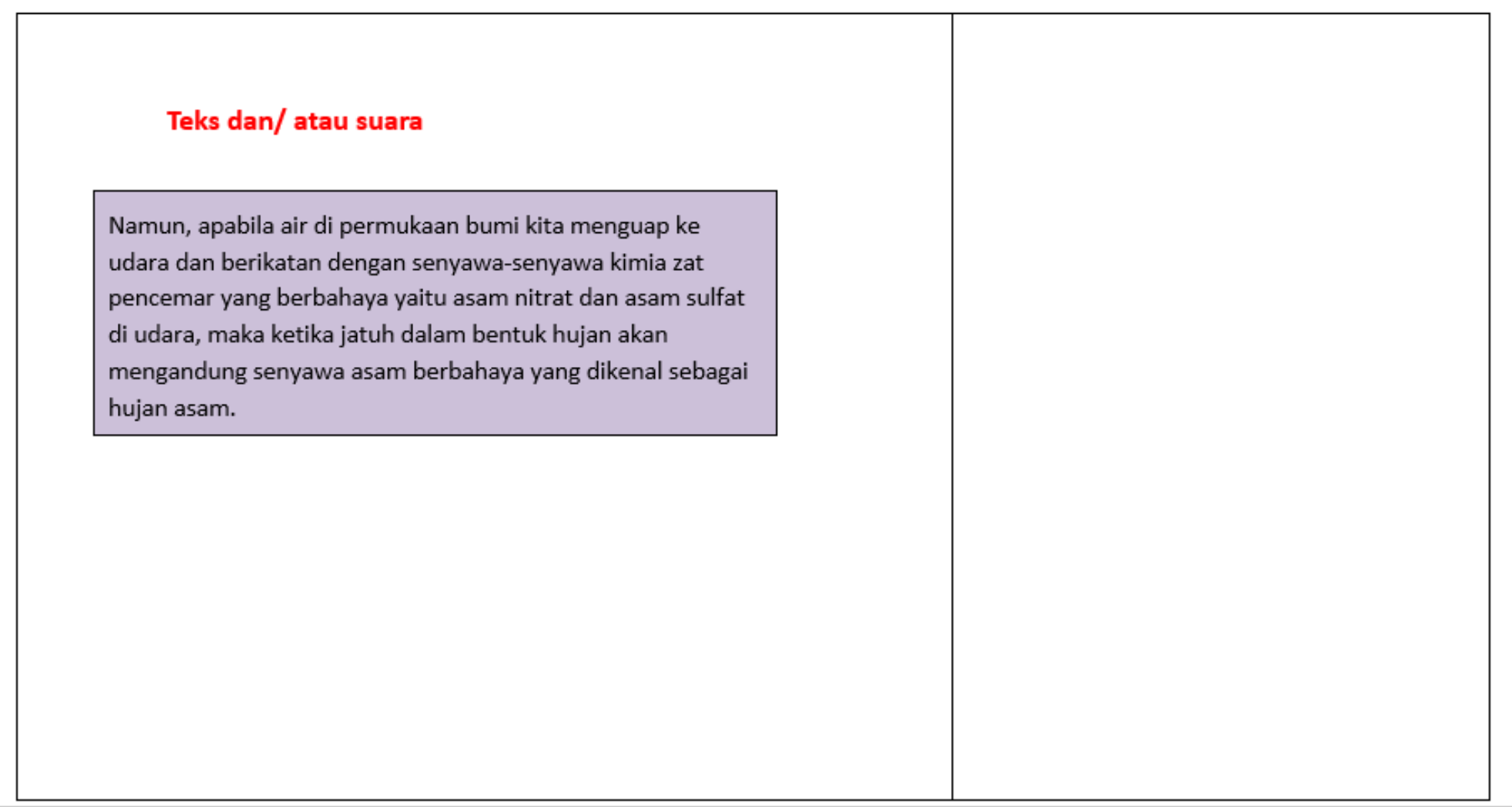

Gambar 2.4. Story Board Multimedia Interaktif dengan Makromedia Flash pada Perkuliahan IPA Terpadu 


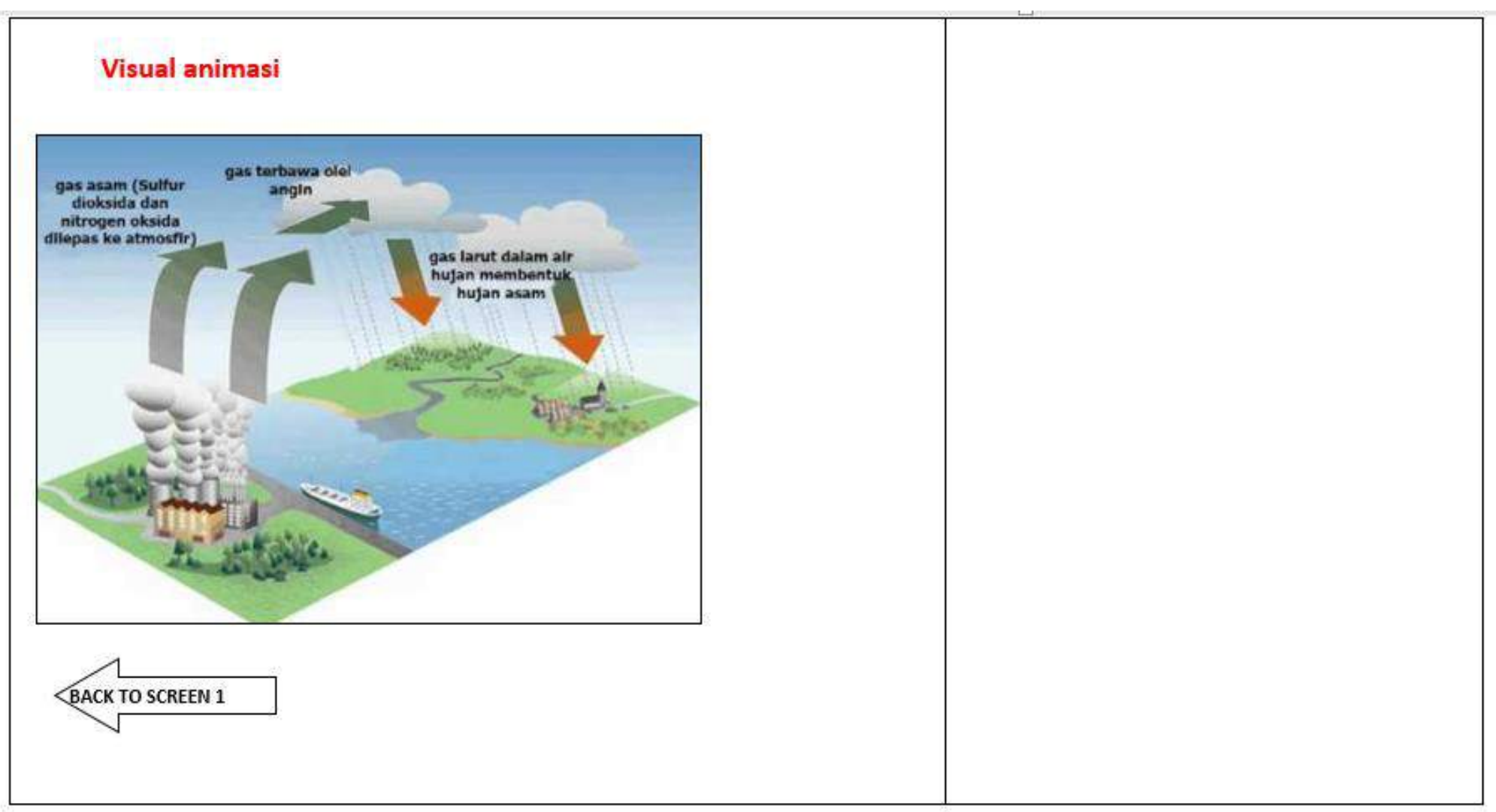

Gambar 2.5. Story Board Multimedia Interaktif dengan Makromedia Flash pada Perkuliahan IPA Terpadu Screen 3 
KOMPETENSI INTI DAN KOMPETENSI DASAR

Kompetensi Inti:

1. Menghayati dan mengamalkan ajaran agama yang dianutnya

2. Menghargai dan menghayati perilaku jujur, disiplin, tanggung jawab, peduli (toleransi, gotong royong), santun, percaya diri, dalam beriteraksi secara efektif dengan lingkungan sosial dan alam jangkauan pergaulan dan keberadaan.

3. Memahami pengetahuan (faktual, konseptual dan prosedural) berdasarkan rasa ingin tahunya tentang ilmu pengetahuan, teknologi, seni, budaya terkait fenomena dan kejadian tampak mata.

4. Mencoba, mengolah, dan menyaji dalam ranah konkret (menggunakan, mengurai, merangkai, memodifikasi, dan membuat) dan ranah abstrak (menulis, membaca, menghitung, menggambar, dan mengarang) sesuai dengan yang dipelajari di sekolah dan sumber lain yang sama dalam sudut pandang/teori

Kompetensi Dasar:

1.1 Mengagumi keteraturan dan kompleksitas ciptaan Tuhan tentang aspek fisik dan kimiawi, kehidupan dalam ekosistem, dan peranan manusia dalam lingkungan serta mewujudkannya dalam pengamalan ajaran agama yang dianutnya.

2.1 Menunjukkan perilaku ilmiah (memiliki rasa ingin tahu; objektif; jujur; teliti; cermat; tekun; hati-hati; bertanggung jawab; terbuka; kritis; kreatif; inovatif dan peduli lingkungan) dalam aktivitas sehari-hari sebagai wujud implementasi sikap dalam melakukan pengamatan, percobaan, dan berdiskusi

2.2 Menghargai kerja individu dan kelompok dalam aktivitas sehari-hari sebagai wujud implementasi melaksanakan percobaan dan melaporkan hasil percobaan

3.9 Mendiskripsikan pencemaran dan dampaknya bagi makluk hidup.

4.11Melakukan penyelidikan untuk menentukan sifat larutan yang di lingkungan sekitar.

1

BACK TO SCREEN 1

Gambar 2.6. Story Board Multimedia Interaktif dengan Makromedia Flash pada Perkuliahan IPA Terpadu Screen 3
1. Ada tombol "kompetensi inti dan kompetensi dasar"

2. Ketika tombol tersebut diklik, maka muncul tulisan kompetensi inti terlebih dahulu selanjutnya disusul dengan munculnya kompetensi dasar secara berurutan

3. Ada tombol "Back to screen

4. Ketika tombol "Back to screen diklik maka muncul halaman muka 


\begin{tabular}{|c|c|}
\hline RINGKASAN MATERI & Screen 4 \\
\hline $\begin{array}{l}\text { PENGERTIAN HUJAN ASAM } \\
\text { Hujan Asam adalah Segala macam hujan dengan pH di bawah 5,6 yang } \\
\text { bersifat basa karena karbondioksida }\left(\mathrm{CO}_{2}\right) \text { di udara yang larut dengan air } \\
\text { hujan memiliki bentuk sebagai asam lemah. }\end{array}$ & $\begin{array}{l}\text { 1. Ada tombol "Ringkasan Materi" } \\
\text { 2. Ketika tombol tersebut diklik, maka muncul } \\
\text { tulisan terkait ringkasan materi secara }\end{array}$ \\
\hline $\begin{array}{l}\text { PENYEBAB HUJAN ASAM } \\
\text { a. Aktivitas manusia seperti industry, pembangkit tenaga listrik, kendaraan } \\
\text { bermotor, dan pabrik pengolahan pertanian. } \\
\text { b. Penggunaan cerobong asap pada pabrik-pabrik pembakaran batu bara } \\
\text { dan minyak bumi } \\
\text { c. penyebab alami hujan asam adalah letusan gunung berapi }\end{array}$ & $\begin{array}{l}\text { bergantian dan berurutan mulai dari } \\
\text { pengertian hujan asam, penyebab hujan asam, } \\
\text { proses hujan asam, dampak hujan asam } \\
\text { 3. Ada tombol "Back to screen } \\
\text { 4. Ketika tombol "Back to screen diklik maka }\end{array}$ \\
\hline $\begin{array}{l}\text { PROSES HUJAN ASAM } \\
\text { Dari proses pembakaran bahan bakar fosil akan dihasilkan berbagai gas. Di antara } \\
\text { gas yang melayang ke udara itu ada zat yang bersifat asam. Zat itu adalah sulfur } \\
\text { dioksida dan nitrogen oksida. } \\
\text { Sulfur dioksida bisa berubah menjadi asam sulfat. Sedangkan nitrogen oksida bisa } \\
\text { menjadi asam nitrat. Keduanya termasuk jenis asam yang kuat. }\end{array}$ & muncul halaman muka \\
\hline
\end{tabular}

Gambar 2.7. Story Board Multimedia Interaktif dengan Makromedia Flash pada Perkuliahan IPA Terpadu Screen 4 


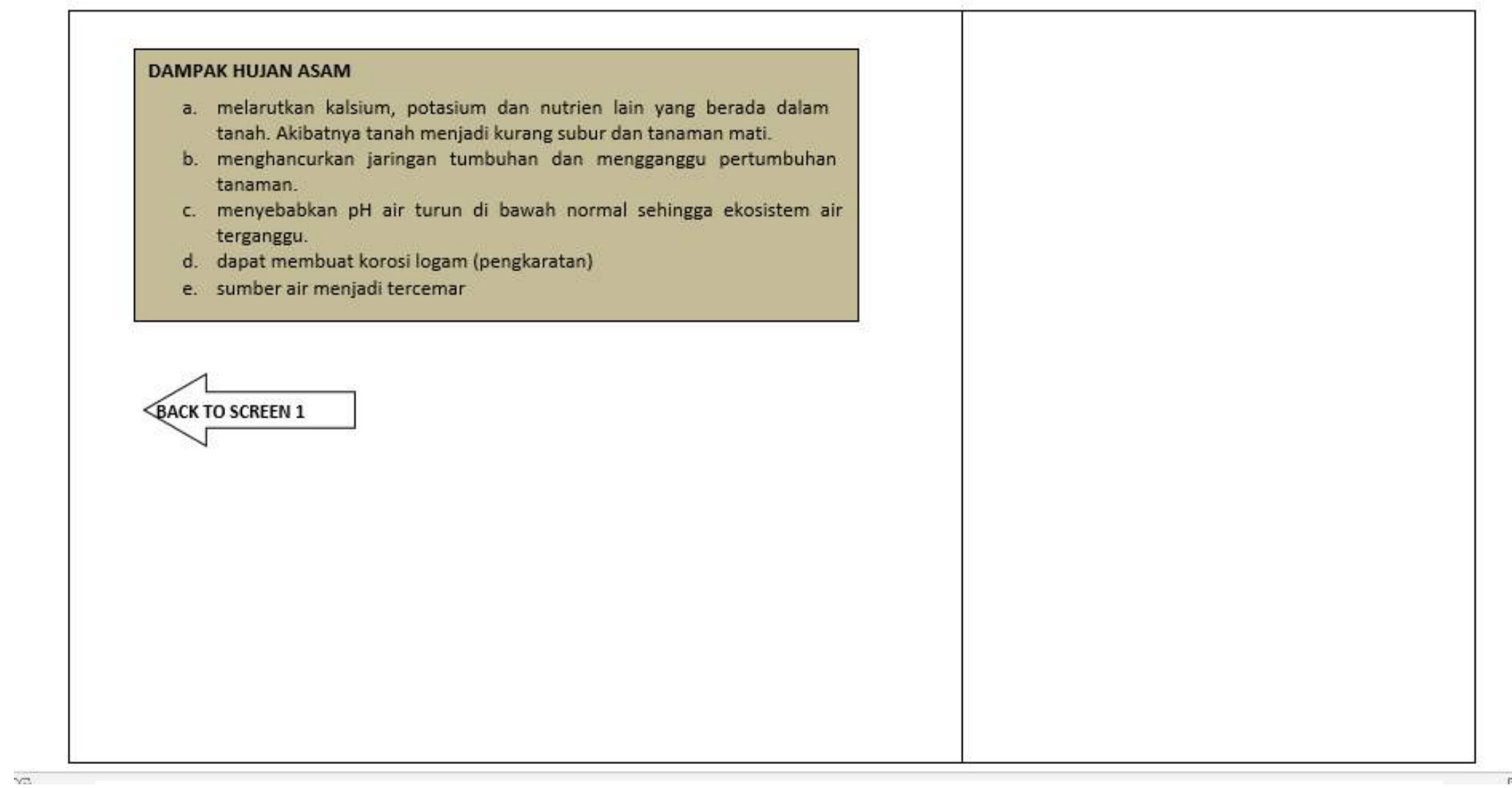

Gambar 2.8. Story Board Multimedia Interaktif dengan Makromedia Flash pada Perkuliahan IPA Terpadu Screen 4 


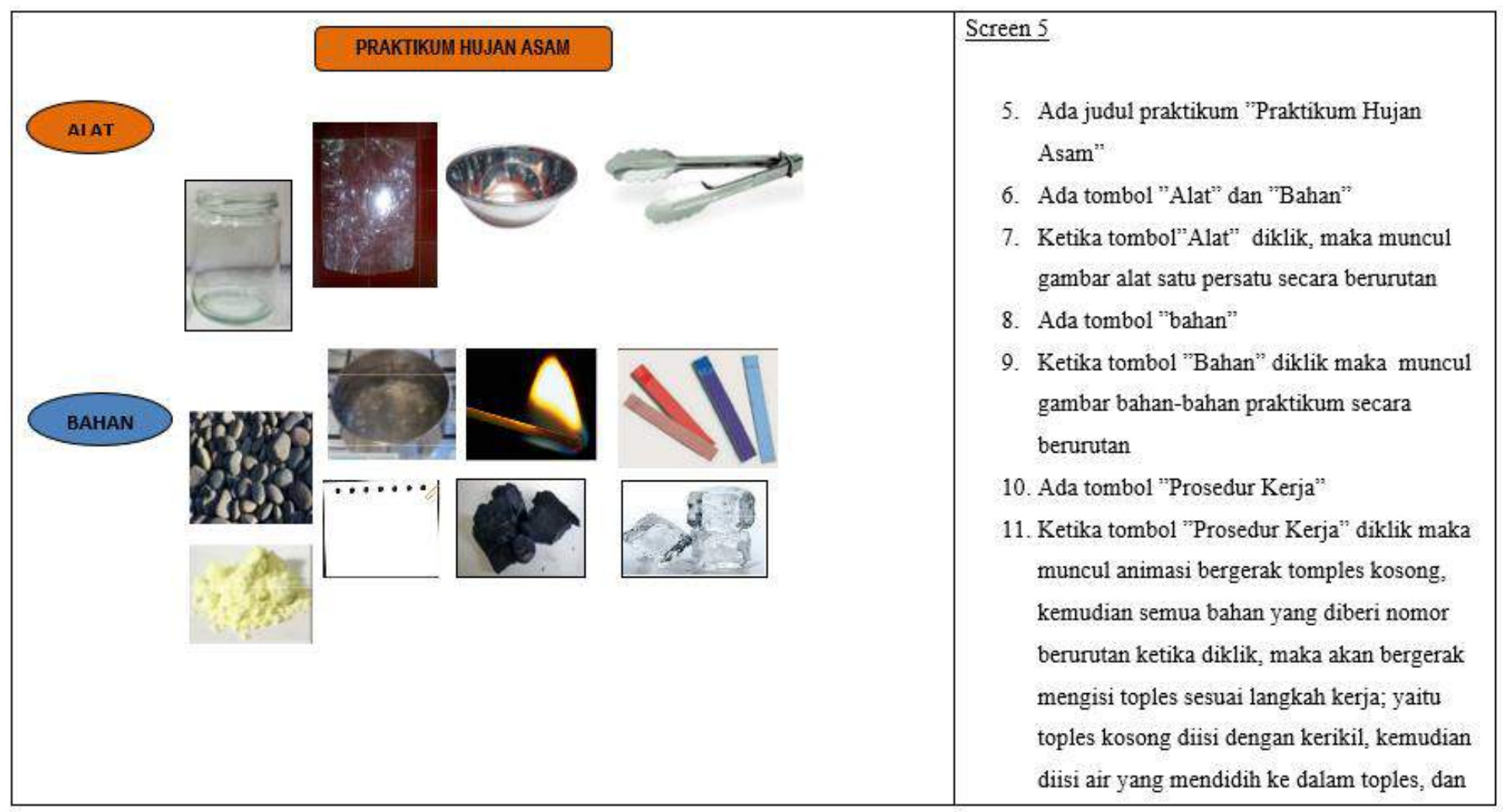

Gambar 2.9. Story Board Multimedia Interaktif dengan Makromedia Flash pada Perkuliahan IPA Terpadu Screen 5 


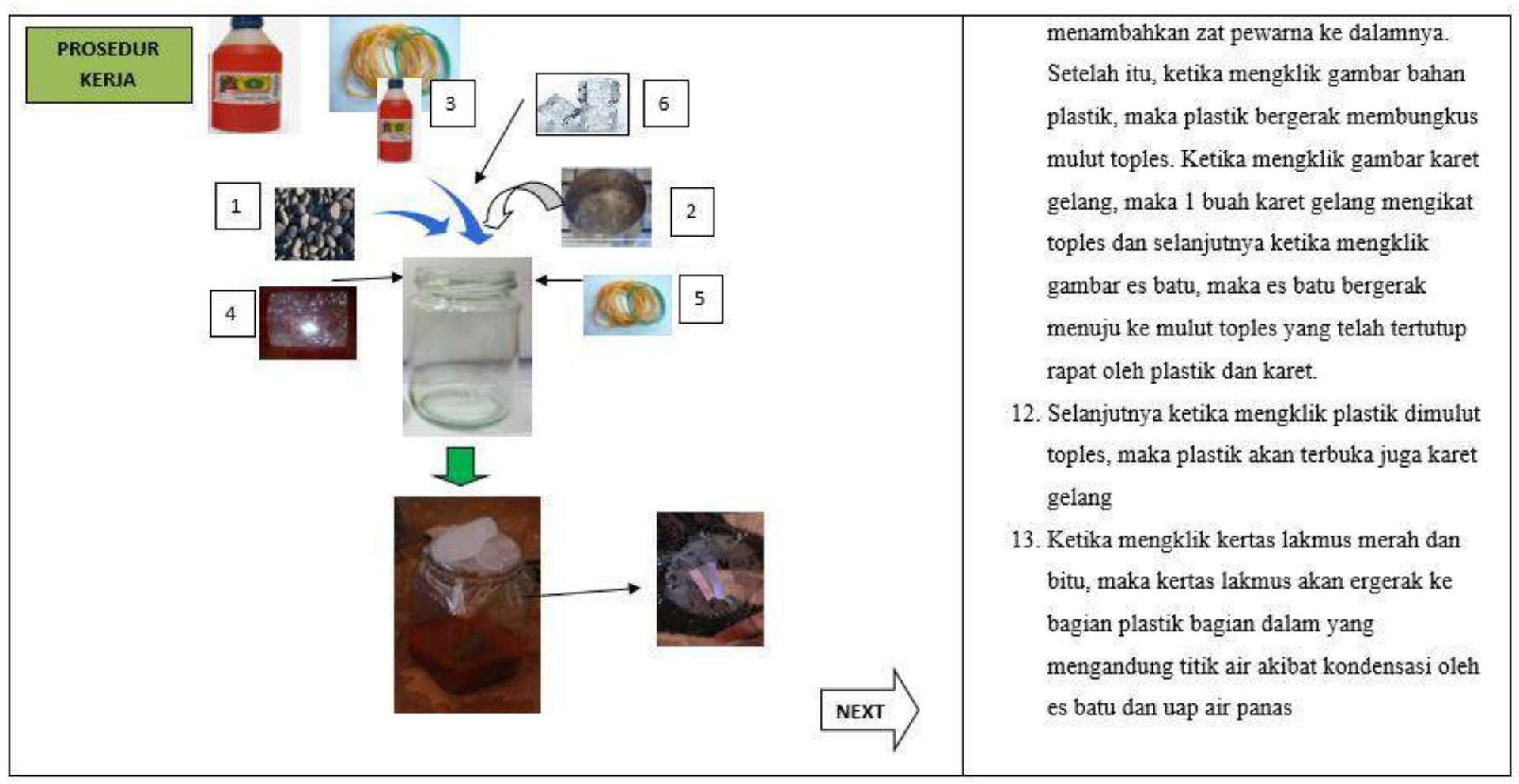

Gambar 2.10. Story Board Multimedia Interaktif dengan Makromedia Flash pada Perkuliahan IPA Terpadu Screen 5 


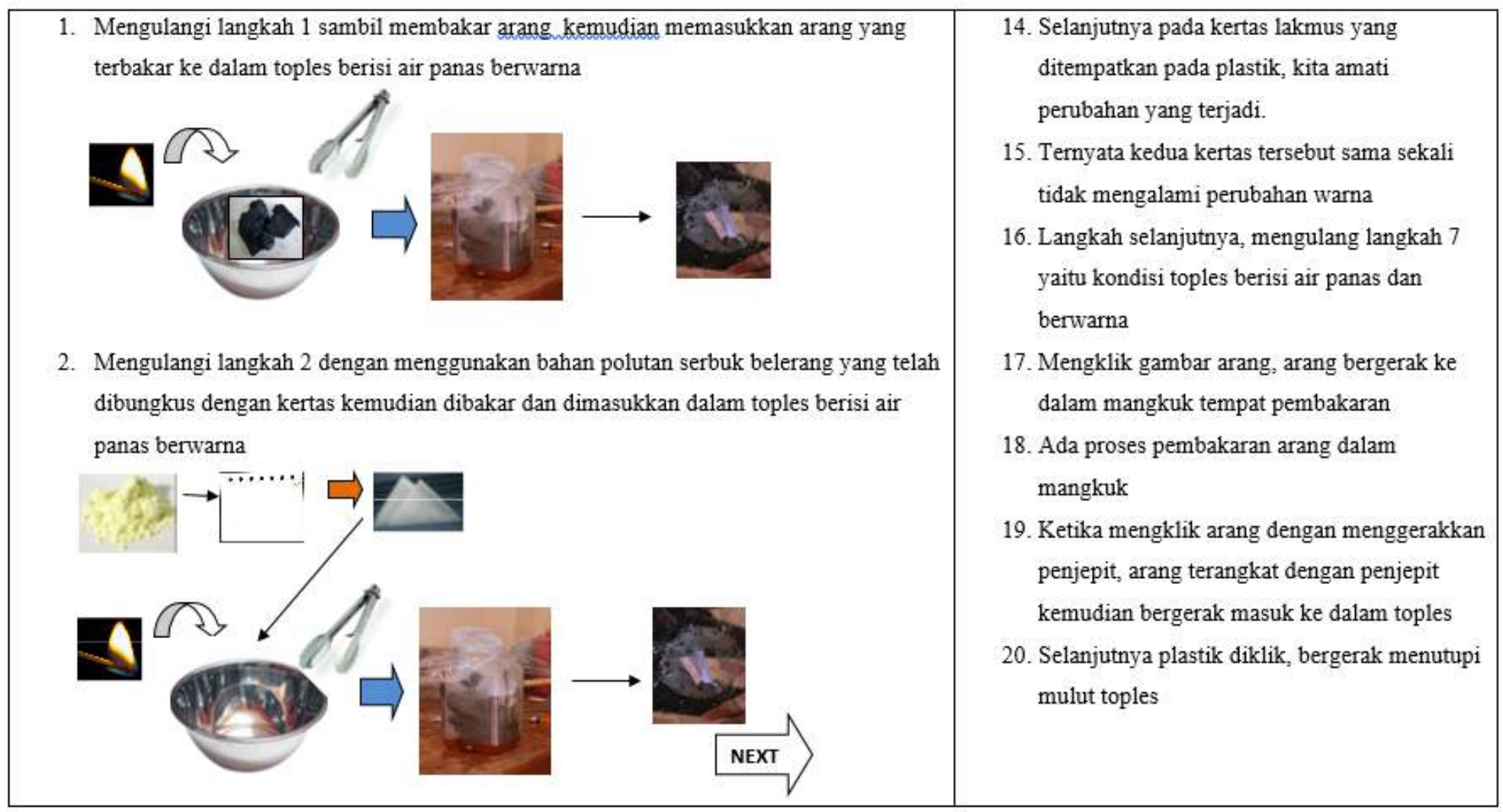

Gambar 2.11. Story Board Multimedia Interaktif dengan Makromedia Flash pada Perkuliahan IPA Terpadu Screen 5 


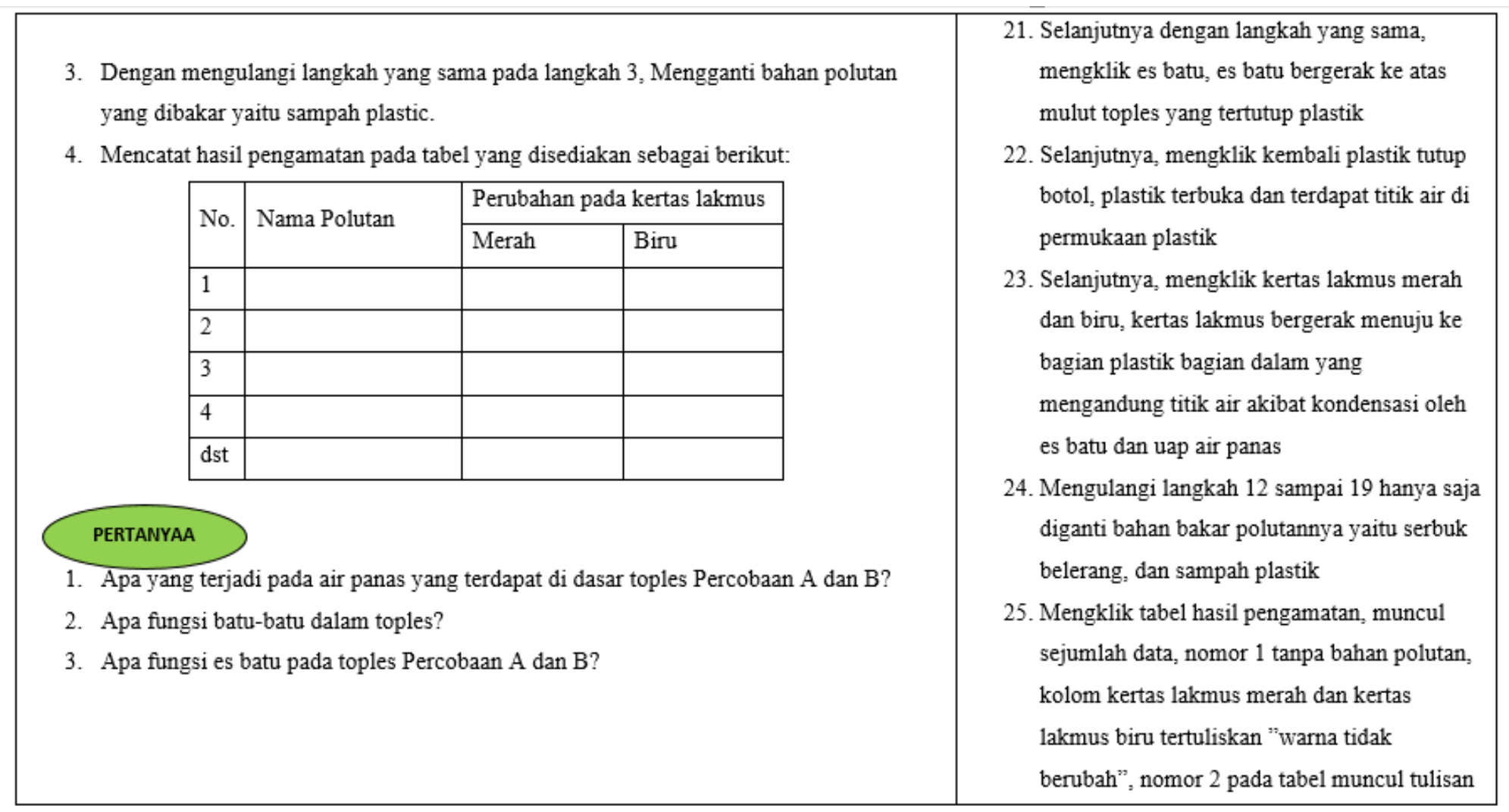

\section{Gambar 2.12. Story Board Multimedia Interaktif dengan Makromedia Flash pada Perkuliahan IPA Terpadu} Screen 5 


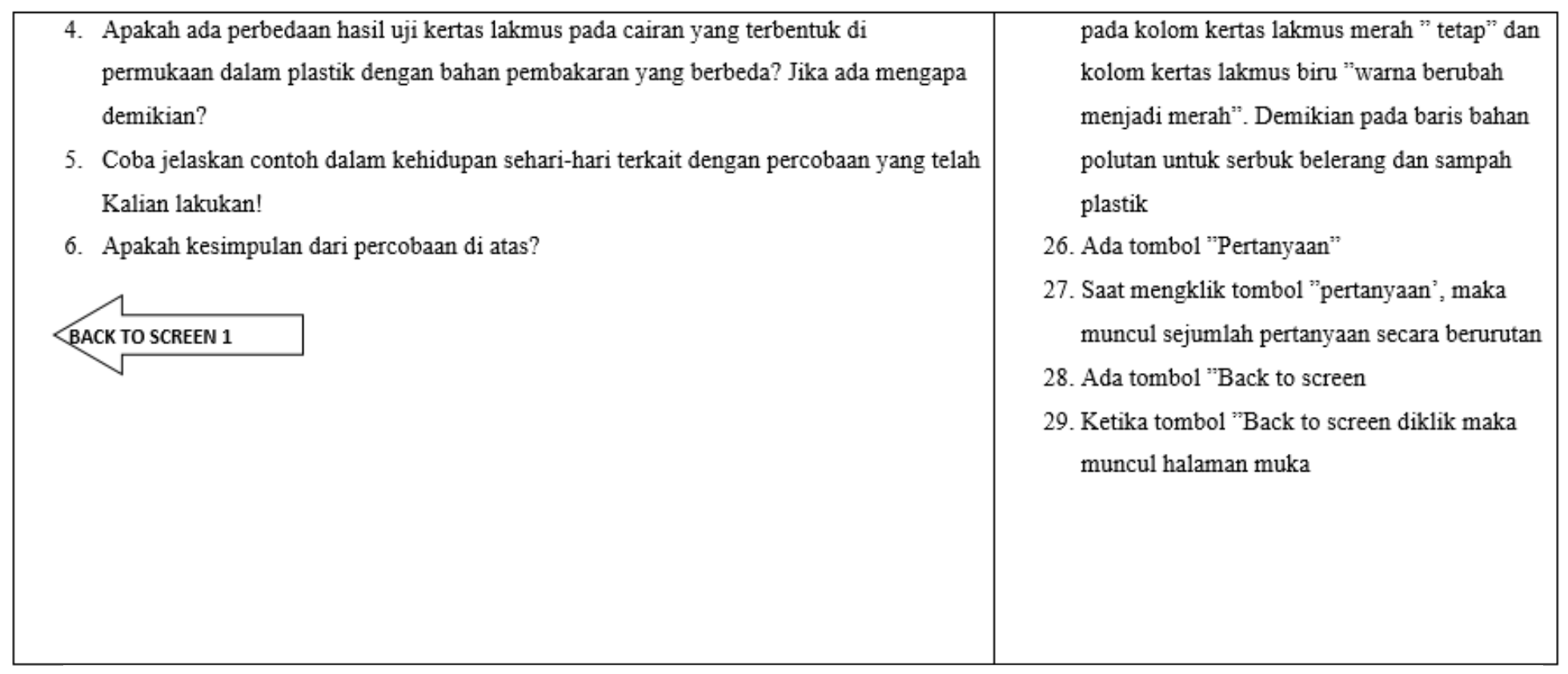

Gambar 2.13. Story Board Multimedia Interaktif dengan Makromedia Flash pada Perkuliahan IPA Terpadu Screen 5 


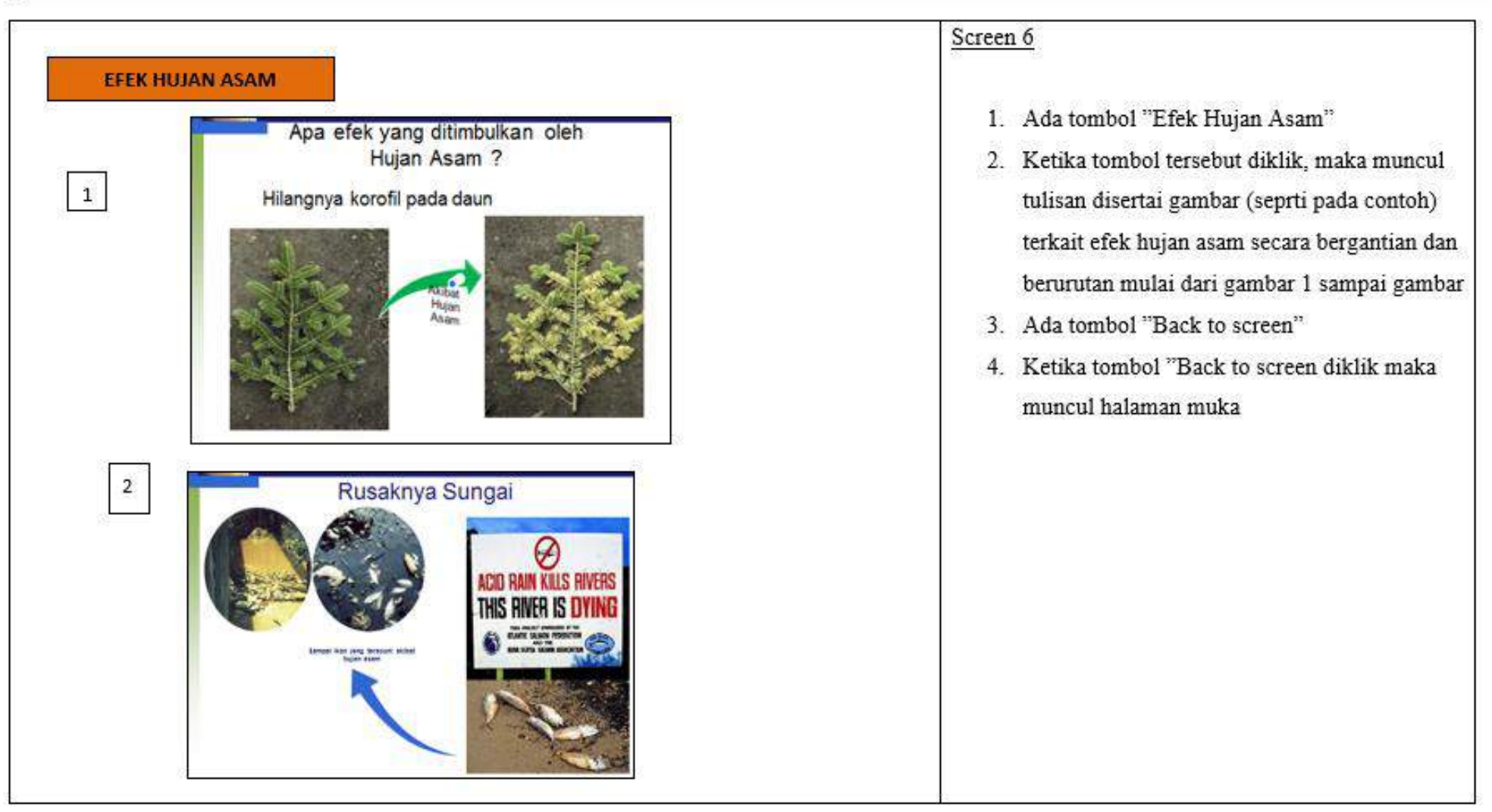

Gambar 2.14. Story Board Multimedia Interaktif dengan Makromedia Flash pada Perkuliahan IPA Terpadu Screen 6 


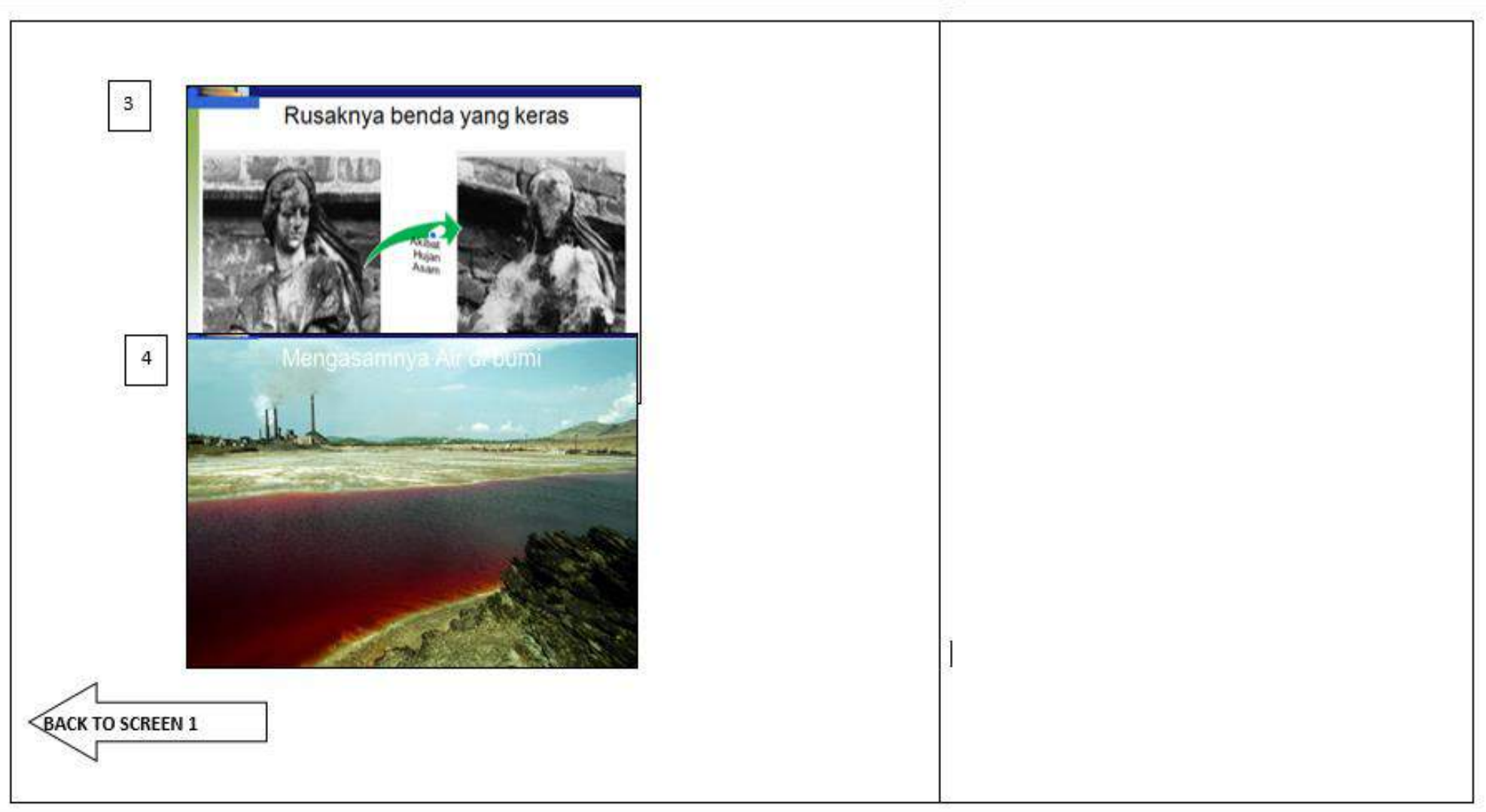

Gambar 2.15. Story Board Multimedia Interaktif dengan Makromedia Flash pada Perkuliahan IPA Terpadu Screen 6 


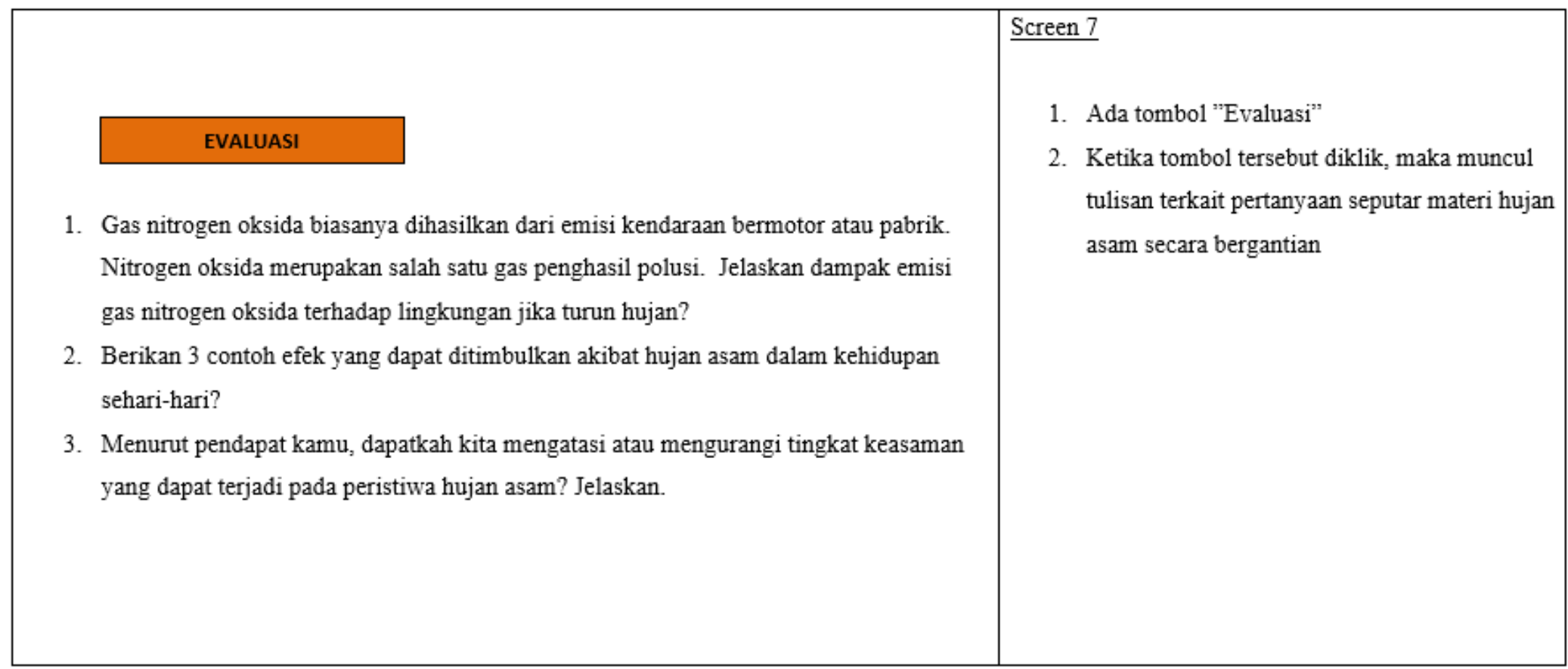

Gambar 2.16. Story Board Multimedia Interaktif dengan Makromedia Flash pada Perkuliahan IPA Terpadu Screen 7 
6. Hasil Uji Coba Software Terintegrasi

Media pembelajaran yang dihasilkan selanjutnya diujicoba dalam rangka mengetahui efektifitas penggunaan media pembelajaran dalam proses perkuliahan IPA Terpadu 1. Hasil menunjukkan bahwa penggunaan media pembelajaran mampu membantu mahasiswa dalam memahami konsep-konsep keipaan dalam hal ini terkait topik pencemaran lingkungan tentang dampak hujan asam bagi kehidupan. Selain itu, penggunaan media macromedia flash dapat mereduksi terjadinya miskonsepsi mahasiswa terkait topik dampak pencemaran hujan asam bagi kehidupan.

Pernyataan di atas didukung oleh perolehan data yang disajikan dalam bentuk grafik pada Gambar 2 berikut. Grafik 2.1 menunjukkan bahwa persentase skor miskonsepsi pada tahap pre test memiliki level yang tinggi pada setiap butir soal dan mengalami penurunan di tahap post test untuk setiap butir soal. Hal ini menunjukkan bahwa perkuliahan dengan pemberian simulasi media pembelajaran Macromedia Flash dapat meminimalisir miskonsepsi. 


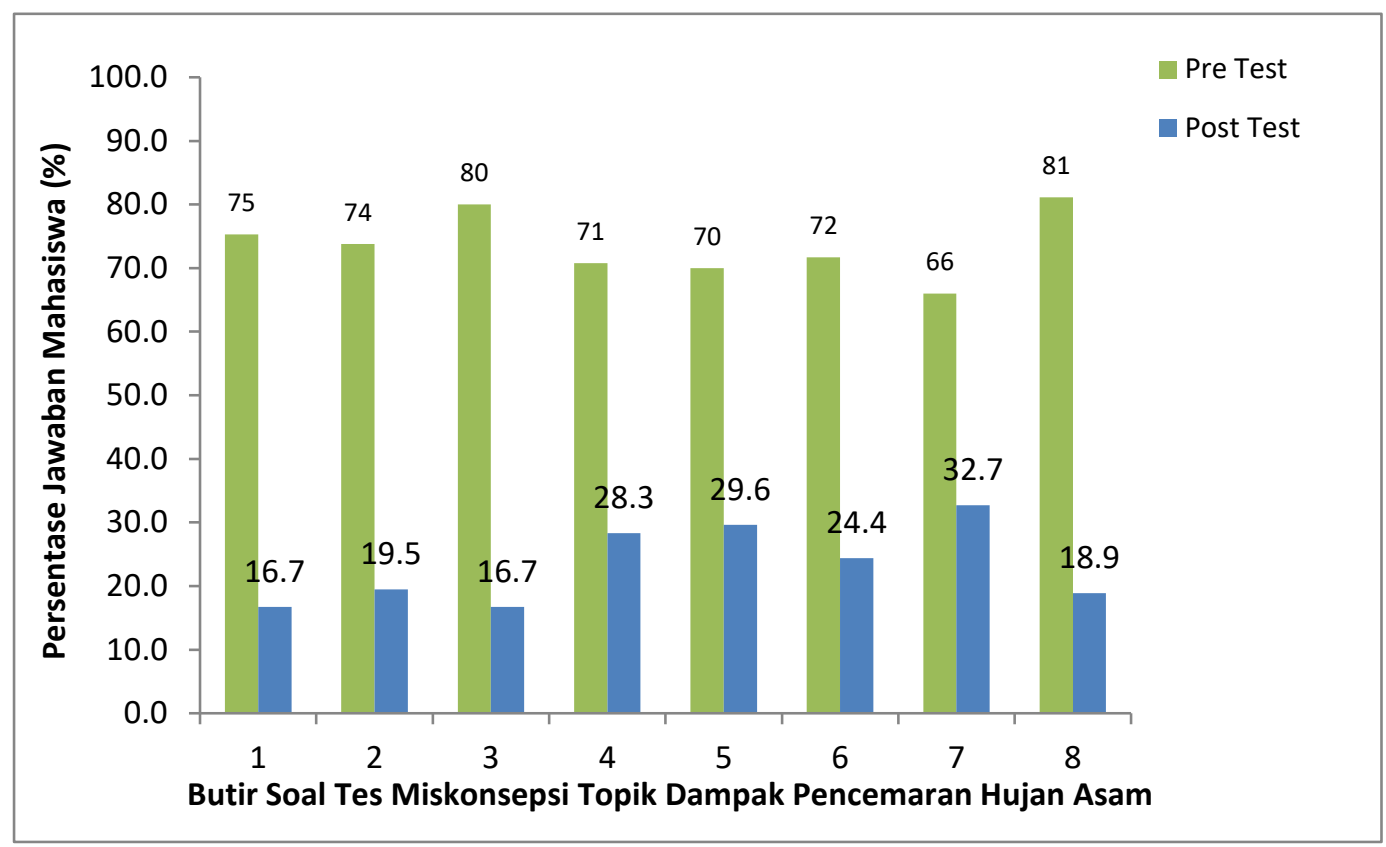

Gambar 2.17 Grafik Persentase Perolehan Skor Tes Miskonsepsi

Mahasiswa Pada Konsep Hujan Asam 


\section{BAB III \\ DUKUNGAN TEORI}

\section{A. Model Pembelajaran yang Berasal dari Teori Belajar Konstruktivisme}

Menurut Bodner (1986), konstruktivis yang pertama ialah Piaget, walaupun perspektif konstruktivis sudah terungkap dalam tulisan Glambattista Vico pada tahun 1970. Melalui perspektif Piaget, pengetahuan diperoleh menurut proses konstruksi selama hidup melalui suatu proses ekuilibrasi antara skema pengetahuan dan pengalaman baru. Antara perspektif Piaget dan perspektif konstruktivis baru terdapat dua perbedaan. Piaget lebih memfokuskan pada general logical capabilities, sedangkan perspektif baru menekankan domain specific knowledge structures. (Ratna, 2011: 152).

Selanjutnya menurut Trianto (2013:28), teori pembelajaran konstruktivis (constructivist theories of learning) merupakan teori baru dalam psikologi pendidikan. Teori konstruktivis ini menyatakan bahwa siswa harus menemukan sendiri dan mentransformasikan informasi kompleks, mengecek informasi baru dengan aturan-aturan lama dan merevisinya apabila aturanaturan itu tidak lagi sesuai. Bagi siswa agar benar-benar memahami dan dapat menerapkan pengetahuan, mereka harus bekerja memecahkan masalah, menemukan segala sesuatu untuk dirinya, berusaha dengan susah payah dengan ide-ide. Teori ini berkembang dari kerja Piaget, Vygotsky, teori-teori pemrosesan informasi, dan teori psikologi kognitif yang lain, seperti teori Bruner.

Menurut teori konstruktivis ini, satu prinsip yang paling penting dalam psikologi Pendidikan adalah bahwa guru tidak hanya sekedar memberikan pengetahuan kepada siswa. Siswa harus membangun sendiri pengetahuan di dalam benaknya. Guru dapat memberikan kemudahan untuk proses ini,dengan 
memberi kesempatan siswa untuk menemukan atau menerapkan ide-ide mereka sendiri, dan mengajar siswa menjadi sadar dan secara sadar menggunakan strategi mereka sendiri untuk belajar, guru dapat memberi siswa anak tangga yang membawa siswa ke pemahaman yang lebih tinggi, dengan catatan siswa sendiri yang harus memanjat anak tangga tersebut.

Esensi dari teori konstruktivis adalah ide bahwa harus siswa sendiri yang menemukan dan mentransformasikan sendiri suatu informasi kompleks apabila mereka menginginkan informasi ini menjadi miliknya. Konstruktivisme adalah suatu pendapat yang menyatakan bahwa perkembangan kognitif merupakan suatu proses di mana anak secara aktif membangun sistem arti dan pemahaman terhadap realita melalui pengalaman dan interaksi mereka. Menurut pandangan konstrukivisme anak secara aktif membangun pengetahuan dengan cara terus menerus mengasimilasi dan mengakomodasi informasi baru, dengan kata lain konstruktivisme adalah teori perkembangan kognitif yang menekankan peran aktif siswa dalam membangun pemahaman mereka tentang realita.

Berpijak pada uraian di atas, maka pada dasarnya aliran konstruktivisme menghendaki bahwa pengetahuan dibentuk sendiri oleh individu dan pengalaman merupakan kunci utama dari belajar bermakna. Belajar bermakna tidak akan terwujud hanya dengan mendengarkan ceramah atau membaca buku tentang pengalaman orang lain.

Belajar menurut pandangan konstruktivis merupakan hasil konstruksi kognitif melalui kegiatan seseorang. Pandangan ini memberi penekanan bahwa pengetahuan kita adalah bentukan kita sendiri (Trianto, 2007). 


\section{B. Model Pembelajaran Konseptual Interaktif (Interactive Conceptual Instruction, ICI)}

Pembelajaran koseptual interaktif (ICI) merupakan landasan pembelajaran keterampilan berpikir. Model pembelajaran ini adalah salah satu alternatif model pembelajaran perubahan konseptual berbasis konstruktivistik. Model ICI yang dikembangkan oleh Savinainen dan Scott (2001) sangat mendukung perkembangan keterampilan berpikir (maha)siswa yang dimulai dari tingkatan pemahaman konsep yang memerlukan suatu proses interaktif yang memberikan peluang mengembangkan gagasan melalui proses dialog dan berpikir.

Model pembelajaran ICI ini terdiri atas empat tahapan yang saling berkesinambungan, yaitu 1) Conceptual focus, pada tahap ini pembelajaran dimulai dengan pendemonstrasian fenomena-fenomena yang berkaitan dengan materi pokok bahasan yang akan dipelajari; 2) Classroom interaction, yaitu merupakan tahap pelibatan siswa dalam interaksi-interaksi kelas dengan tujuan memberikan kesempatan pada siswa untuk mengembangkan gagasan melalui proses berpikir; 3) Research-based material, pada tahap ini siswa melakukan pertanyaan dan menjawab permasalahan yang terbentuk pada tahap 1 dalam pembentukan makna. Tahap ini juga berfungsi sebagai asesmen yang dapat mengukur pemahaman siswa. Selain itu tahap ini juga dapat difungsikan sebagai acuan dalam pembelajaran lebih lanjut; dan tahap 4) Use of text, pada tahap ini pebelajar dan guru dapat menggunakan buku teks dengan maksud untuk meningkatkan pemahaman siswa secara mendalam. Selain itu dapat melibatkan siswa dalam proses berpikir metakognitif, keterampilan berpikir kritis, dan kreatif dan menghubungkan pengetahuan yang diperoleh melalui diskusi dengan pengetahuan yang didapatkan dari buku (Savinainen \& Scott, 2004). 


\section{Tahapan Model Pembelajaran Konseptual Interaktif (Interactive Conceptual Instruction, ICI)}

Dalam beberapa penelitian yang dikembangkan, terbukti berhasil meningkatkan hasil belajar dan pemahaman konsep fisika dibandingkan dengan pendekatan konvensional.

Dalam pembelajaran konseptual interaktif, siswa berpartisipasi aktif dalam proses pembelajaran. Salah satu kebaikan model pembelajaran interaktif adalah siswa belajar mengajukan pertanyaan, mencoba merumukan pertanyaan, dan mencoba menemukan jawaban terhadap pertanyaan sendiri dengan melakukan kegiatan observasi (penyelidikan) (Suprayetkti, 2008). Dengan cara seperti itu, siswa menjadi kritis dan aktif belajar. Model pembelajaran Interactive Conseptual Instruction (ICI) terdiri dari empat tahap, yaitu :

1. Berfokus pada konseptual (conceptual focus),

2. Penggunaan buku teks secara efektif (use of textbook)

3. Material berbasis penelitian (research based materials), dan

4. Interaksi kelas (classroom interaction) (Savinainen, 2004).

Keempat tahapan ini saling berkaitan dan mendukung keberhasilan proses pembelajaran. Secara garis besar, tahap-tahap dalam model pembelajaran ICI disajikan pada Gambar berikut.

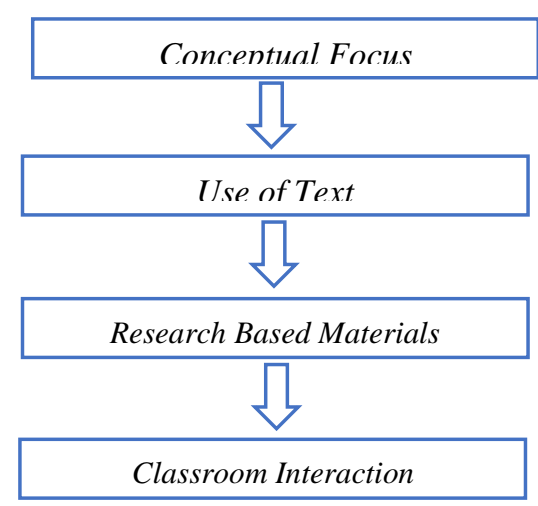

Gambar Tahap-tahap Model Pembelajaran ICI 
Tahap pertama adalah berfokus pada konseptual (conceptual focus). Pembelajaran dimulai dengan demonstrasi fenomena yang bertindak sebagai fokus pengamatan dan diskusi sampai ke pengenalan konsep-konsep relevan oleh guru (Santyasa et al., 2004). Pada model Interactive Conceptual Instruction (ICI), conceptual focus diperoleh dengan menggunakan prinsipprinsip dan konsep-konsep, di mana ide-ide baru pertama tama dikembangkan pada level konseptual dengan sedikit mungkin atau tanpa penggunaan matematik.

Tahap kedua melibatkan penggunaan buku teks (use of textbook) untuk mengkonstruksi pemahaman secara mendalam. Teks ajar fisika yang digunakan dalam pembelajaran dengan model ICI adalah teks ajar yang berfungsi sebagai refutational text (teks sangkalan). Refutational text ini berbeda dengan buku teks yang bersifat konvensional. Refutational text ini menyajikan masalah, miskonsepsi, sangkalan, konsep dan prinsip, contohcontoh kontekstual, dan pertanyaan-pertanyaan untuk memandu sikap positif, pemahaman konsep, pemecahan masalah, dan ketarampilan menggunakan pengetahuan secara bermakna.

Tahap ketiga melibatkan penggunaan material berbasis penelitian (research based materials). Pada tahap ini siswa diberi kesempatan melakukan demonstrasi atau praktikum untuk membuktikan kebenaran konsep yang diajukan. Melalui demonstrasi atau praktikum ini akan memberikan sebuah kebenaran dari sebuah hipotesis yang telah diramalkan dan pendapat yang disampaikan oleh siswa. Selain itu, hasil demonstrasi atau praktikum ini juga dapat membenahi miskonsepsi yang dimiliki oleh siswa terkait materi yang dibahas.

Tahap keempat adalah melibatkan interaksi kelas (classroom interaction). Tahap ini didasari oleh premis bahwa pembuatan makna (meaning making) merupakan proses dialog antarkomunitas kelas untuk 
mengembangkan gagasan melalui proses berpikir. Pada proses interaksi ini, siswa akan mendapatkan keberanian untuk mengemukakan argumentasinya dan sharing pengetahuan antarsesamanya. Proses pembelajaran yang interaktif akan menghindarkan siswa sebagai penerima pasif, tetapi akan menuntun siswa menjadi pebelajar yang aktif baik secara mental maupun fisik. Interaksi siswa dalam kelas dapat ditumbuhkan melalui kegiatan pembelajaran kooperatif.

\section{Rasionalitas Penggunaan Pembelajaran Konseptual Interaktif dalam Proses Pembelajaran Sains}

Interaksi yang baik diperlukan dalam suatu proses belajar mengajar. Hal ini dikemukakan oleh Siregar (1998) bahwa upaya mengkonstruksi pengetahuan diwujudkan melalui interaksi kognitif komponen-komponen materi subyek, pengajar, dan pembelajar yang saling menguntungkan. Dalam hal ini, pengajar (guru) bertindak sebagai pemberi pesan dalam interaksi antar materi subyek, pebelajar sebagai penerima pesan, dan materi subyek adalah pesan yang disampaikan. Materi subyek yang dimaksud adalah pengetahuan.

Salah satu faktor yang menunjang keberhasilan menghantarkan pebelajar untuk memiliki pengetahuan dan kemampuan baru yaitu penggunaan alat bantu atau media pembelajaran yang sesuai dengan konten materi subyek. Pernyataan ini dipertegas oleh pernyataan Arifin (2000) bahwa media pembelajaran yang relevan akan menjadikan proses belajar mengajar berlangsung efektif dan efisien atau dengan kata lain mencapai tujuan dengan cepat dan atau mudah.

Multimedia interaktif merupakan salah satu model mutakhir dalam pemanfaatan teknologi komunikasi dan informasi (ICT) melalui komputer yang merupakan starting point terhadap pemilihan pendekatan praktek 
investigasi pembelajaran sains. Ada dua hal yang menjadi tujuan utama mengajarkan sains yaitu terkait konten teori dan proses penalaran ilmiah (Hennessy et.al., 2007).

Jenis multimedia interaktif yang menjadi fokus penelitian ini yaitu media simulasi dan virtual lab. (dry lab). Multimedia interaktif jenis simulasi memberikan kontribusi berkekuatan penuh dari aplikasi ICT dalam pendidikan sains saat ini. Multimedia simulasi ini mampu menganimasikan dan mensimulasikan proses secara nyata, misalnya gerak, fotosintesis, difusi, atau ikatan atom. Selain itu multimedia jenis ini memberikan kesempatan kepada peserta didik untuk mengelola "eksperimen virtual" yang dinyatakan tidak aman (berbahaya), berbiaya tinggi dan beberapa hal lain yang tidak dapat dijangkau pada laboratorium nyata sains.

\section{E. Penggunaan Media dalam Pembelajaran Konseptual Interaktif}

Tidak semua yang dipelajari oleh siswa adalah hal-hal yang konkret. Banyak pula konsep-konsep abstrak yang menuntut pemahaman siswa dalam mempelajarinya. Untuk mempermudah siswa dalam mempelajari hal-hal abstrak dapat digunakan media. Media merupakan perantara yang membantu memperjelas materi pelajaran. Media juga dipercaya dapat membantu guru dalam mempermudah serta mengatasi masalah komunikasi yang dialami oleh guru ketika mengajarkan suatu materi. Walaupun demikian, tentu posisi dan peran guru di kelas tidak dapat digantikan oleh media, karena media hanya berupa alat bantu yang memfasilitasi guru dalam pembelajaran (Suprihatiningrum, 2013).

Media pembelajaran berasal dari Bahasa latin yaitu bentuk jamak dari medium yang dapat didefenisikan sebagai medium dan penyampai pesan (Sanjaya, 2011). Media pembelajaran berdasarkan Sadiman dalam Warsita (2008) adalah kombinasi antara materi dan alat atau kombinasi dari software 
dan hardware. Media pembelajaran dapat pula disebut sebagai alat yang digunakan untuk mencapai tujuan dalam proses pembelajaran.

Selain itu, (Rosyid,2019) mengatakan media pembelajaran juga memiliki pengaruh besar atas terciptanya proses belajar yang menyenangkan bagi siswa, yang nantinya kan berdampak pada kualitas pembelajaran. Karena media pembelajaran akan membantu siswa dalam memahami materi yang sulit dengan memberikan pemahaman yang lebih mudah dan jelas melalui media pembelajaran.

Penggunaan media pembelajaran secara umum diperlukan dalam kaitannya dengan peningkatan mutu Pendidikan. Media pembelajaran di sekolah digunakan dengan tujuan antara lain sebagai berikut :

1. Memberikan kemudahan kepada siswa untuk lebih memahami konsep, prinsip dan keterampilan tertentu dengan menggunakan media yang paling tepat menurut sifat bahan ajar.

2. Memberikan pengalaman belajar yang berbeda dan bervariasi sehingga lebih merangsang minat dan motivasi siswa untuk belajar.

3. Menumbuhkan sikap dan keterampilan tertentu dalam teknologi karena siswa tertarik untuk menggunakan atau mengoperasikan media tertentu.

4. Menciptakan situasi belajar yang tidak dapat dilupakan siswa.

5. Memperjelas informasi atau pesan pembelajaran.

6. Meningkatkan kualitas belajar mengajar.

Penggunaan media dalam pembelajaran harus sesuai dengan tingkat perkembangan siswa dan berorientasi pada proses pembelajaran agar lebih menyenangkan.

Gagne dan Briggs mengemukakan bahwa media pembelajaran meliputi alat yang secara fisik digunakan untuk menyampaikan isi materi pembelajaran yang terdiri dari, antara lain : buku, tape-recorder, kaset, video 
kamera, video recorder, film, slide (gambar bingkai), foto gambar, grafik, televisi, dan komputer (Arsyad, 2013).

Salah satu bentuk aplikasi pemanfaatan teknologi komputer dalam pembelajaran yaitu pembuatan multimedia interaktif. Multimedia interaktif adalah salah satu media berbasis teknologi komputer yang menggabungkan dan mengintegrasikan seluruh media yang meliputi teks, grafis, foto, video, animasi, music, narasi, dan interaktivitas yang terprogram dengan menggunakan prinsip dan teori belajar. Multimedia interaktif merupakan multimedia yang dilengkapi dengan alat pengontrol yang dapat dioperasikan oleh pengguna, sehingga pengguna dapat memilih apa yang dikehendaki untuk proses selanjutnya. Karakteristik dari media ini berdasarkan Warsita (2008) adalah: kondisi siswa, dan dibawah kendali pengguna, belajar menekankan dan diorganisasi berdasarkan pengetahuan kognitif, sehingga pengetahuan dikonstruksi selama siswa menggunakan media.

Terdapat beberapa bentuk format multimedia pembelajaran interaktif, diantaranya yaitu simulasi dan percobaan atau eksperimen. Multimedia dengan format simulasi menyamai proses dinamis yang terjadi di dunia nyata, misalnya untuk mensimulasikan pesawat terbang, dimana pengguna seolaholah melakukan aktifitas menerbangkan pesawat terbang.

Format lainnya yaitu percobaan dan eksperimen. Format ini mirip dengan format simulasi, namun lebih ditujukan pada kegiatan-kegiatan yang bersifat eksperimen, seperti kegiatan praktikum di laboratorium IPA, biologi atau kimia. Jenis format ini diistilahkan dengan virtual laboratorium atau istilah lainnya dry lab. Pada program ini menyediakan serangkaian peralatan dan bahan, kemudian pengguna bisa melakukan percobaan atau eksperimen sesuai petunjuk dan kemudian mengembangkan eksperimen-eksperimen lain berdasarkan petunjuk tersebut. Diharapkan pada akhirnya pengguna dapat 
menjelaskan suatu konsep atau fenomena tertentu berdasarkan eksperimen yang mereka lakukan secara maya tersebut. 


\section{BAB IV \\ KESIMPULAN}

Simpulan dari monograf ini :

1. Model pembelajaran konseptual interaktif (Interactive Conceptual Instruction, ICI) berasal dari teori belajar konstruktivisme.

2. Model pembelajaran konseptual interaktif terdiri dari empat tahapan, yaitu : berfokus pada konseptual (conceptual focus), penggunaan buku teks (use of textbook), material berbasis penelitian (research based materials), dan interaksi kelas (classroom interaction).

3. Model pembelajaran konseptual interaktif dengan menggunakan multimedia interaktif berupa macromedia flash dapat membantu siswa memahami materi yang bersifat abstrak seperti pada materi dampak pencemaran hujan asam. 


\section{DAFTAR PUSTAKA}

Arsyad, Azhar. 2013. Media Pembelajaran. Jakarta: PT.Grafindo Persada.

Cahyanti, et al., 2012. "Model Pembelajaran Konseptual Interaktif Berorientasi pada Kemampuan Penalaran Berpengaruh Terhadap Hasil Belajar Matematika". Artikel ilmiah (online). Tersedia: http://www.google.co.id/search:Diakses 1 Mei 2016.

Dahar, Ratna Wilis. 2011. Teori-teori Belajar dan Pembelajaran. Jakarta: Erlangga.

Magfiroh, Q, et al., 2014. "Penerapan Model Pembelajaran Konseptual Interaktif untuk Meningkatkan Kemampuan Pemahaman Konsep Matematika Siswa SMP”. Artikel ilmiah (online). Tersedia: http://www.google.co.id/search.Diakses 1 Mei 2016.

Marisda, D H. 2018. Model Pembelajaran Konseptual Interaktif dalam Mata Kuliah IPA Terpadu. Prosiding. Disajikan dalam Simposium Fisika Nasional (SFN)-XXXI pada tanggal 21-22 September 2018 di Grand Inna Hotel Medan.

Rosyid, et al., 2019. Ragam Media Pembelajaran. Malang: Rineka Cipta.

Sanjaya, W. 2011. Pembelajaran dan Desain Sistem Pembelajaran. Jakarta: Kencana Prenada Media Grup.

Santyasa, I W. 2004. Model Problem Solving dan Reasoning sebagai Alternatif Pembelajaran Inovatif. Makalah. Disajikan dalam Konvensi Nasional Pendidikan Indonesia (Konaspi) V pada tanggal 5-9 Oktober 2004, di Surabaya. 
Savinainen, A \& Scott,P. 2004. "Using the Force Concept Inventory to Monitor Student Learning and to Plan Teaching”. Phys.Educ. 37(1) 53-58.

Suhandi, A. et al., 2013. "Efektivitas Penggunaan Media Simulasi Virtual pada Pendekatan Pembelajaran Konseptual Interaktif dalam Meningkatkan Pemahaman Konsep dan Meminimalkan Miskonsepsi”. Artikel ilmiah (online). Tersedia: http: //www.file.upi.edu/../artikel_2.pdf. Diakses 1 Mei 2016.

Suprihatiningrum, Jamil. 2013. STRATEGI PEMBELAJARAN: Teori dan Aplikasi. Jogjakarta: Ar-Ruzz Media.

Trianto. 2007. Model Pembelajaran Terpadu dalam Teori dan Praktek. Jakarta: Prestasi Pustaka.

, 2013. MENDESAIN MODEL PEMBELAJARAN INOVATIFPROGRESIF: Konsep, Landasan, dan Implementasinya pada Kurikulum Tingkat Satuan Pendidikan (KTSP). Jakarta: Kencana Prenada Media Grup.

Warsita, B. 2008. Teknologi Pembelajaran: Aplikasi dan Landasan. Jakarta: Rineka Cipta. 


\section{TENTANG PENULIS}

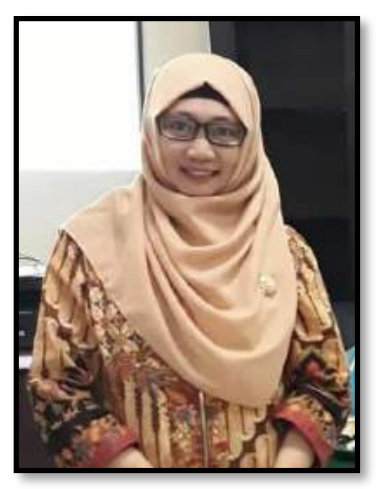

Dewi Hikmah Marisda, S.Pd., M.Pd, lahir di Makassar, 14 Januari 1987. Anak pertama dari dua bersaudara, pasangan Bapak Muhammad Sain dan Ibu Nurwanati Nawawi.

Pendidikan formal ditempuh dari SDN KIP BARAYA Makassar, SMPN 10 Makassar, dan SMAN 5 Makassar. Pendidikan tinggi ditempuh dari Pendidikan Fisika, FMIPA, Universitas Negeri Makassar lulus tahun 2010, kemudian melanjutkan ke Pascasarjana Universitas Negeri Makassar (20122014).

Penulis sekarang berprofesi sebagai Tenaga Pengajar di Program Studi Pendidikan Fisika, Fakultas Keguruan dan Ilmu Pendidikan Universitas Muhammadiyah Makassar (2015-sekarang). Sebelum berprofesi sebagai dosen, ia berprofesi sebagai Guru Fisika di SMK Kesehatan Terpadu Mega Rezky Makassar (2010-2015). 
Buku Monograf ini bertujuan memberikan gambaran tentang model pembelajaran yang tepat digunakan pada perkuliahan IPA Terpadu. Buku ini juga menjelaskan penggunaan media pembelajaran interaktif yang disandingkan dengan model pembelajaran konseptual interaktif pada perkuliahan IPA Terpadu. Selanjutnya, buku monograf ini diharapkan dapat menjadi referensi bagi pemerhati pendidikan dan masyarakat pada umumnya dalam hal menambah khasanah pengetahuan dalam bidang pendidikan, khususnya proses pembelajaran. 
